\title{
Institutional Waste within the UK Construction Procurement Context: A Conceptual Framework
}

\author{
Saad Sarhan ${ }^{1 *}$, Christine Pasquire ${ }^{2}$, Andrew King ${ }^{3}$, and Emmanuel Manu ${ }^{4}$
}

\begin{abstract}
There is a broad consensus among social and economic researchers that 'institutions' matter. Institutions influence beliefs, norms and actions; thus they shape performance and outcomes. Interestingly, the concept of institutions is not well established in construction economics or management research, specifically in waste-related literature. This paper presents discussions on the impact of imperfect regulations, norms and cultural/cognitive assumptions that exist within the construction procurement context, and how this has translated into the institutionalisation of wasteful behaviours and practices in construction projects. Based on a critical review of extant literature, the ultimate objectives of this study are to: (1) contribute to the overall understanding of waste in construction by suggesting a novel perspective to the generation and persistence of waste in construction projects; (2) demonstrate how the neo-institutional theory, a branch of organizational sociology, can potentially be applied as an analytical lens to deliver a more explicit theory of waste that relates cause and effect within the wider aspects of construction procurement systems and relationships; (3) highlight a number of widely accepted regulations, norms and meanings that impede efficiency and improvement efforts in construction; and (4) formulate propositions on institutional waste in the process of construction procurement that will be fundamental to the future trajectory of this study.
\end{abstract}

\section{Keywords}

Waste, Institutional theory, Lean Construction, Construction Procurement, Organisational Studies

\footnotetext{
${ }^{1}$ School of Architecture and the Built Environment, University of Lincoln, Brayford Pool, Lincoln, Lincolnshire, ssarhan@lincoln.ac.uk (corresponding author)

${ }^{2}$ School of Architecture, Design, and the Built Environment, Nottingham Trent University, 50 Shakespeare Street, Nottingham, Nottinghamshire, christine.pasquire@ntu.ac.uk

3 School of Architecture, Design, and the Built Environment, Nottingham Trent University, 50 Shakespeare Street, Nottingham, Nottinghamshire, Andrew.king@ntu.ac.uk

4 School of Architecture, Design, and the Built Environment, Nottingham Trent University, 50 Shakespeare Street, Nottingham, Nottinghamshire, Emmanuel.manu@ntu.ac.uk
} 


\section{Introduction}

It is widely accepted that there is considerable waste in the end-to-end design, construction and facility management process. Over the past sixty years the industry has commissioned several reports with the aim of reviewing its performance and suggesting means of improvement. Of these, the Egan report, 'Rethinking Construction', was produced in 1998 to address concerns raised by clients engaging services of construction companies; and was followed by the 'Never Waste A Good Crisis' report published by construction excellence in 2009 to review the subsequent progress. The former report sent a clear message to the construction industry by stressing that:

"Recent studies in the USA, Scandinavia and this country suggest that up to $30 \%$ of construction is rework, labor is used at only 40-60\% of potential efficiency, accidents can account for 3-6\% of total project costs, and at least $10 \%$ of materials are wasted...The message is clear - there is plenty of scope for improving efficiency and quality simply by taking waste out of construction" (Egan, 1998, p.15).

Empirical evidence points to waste in excess of $50 \%$ of construction time (Figure 1), where waste is defined as anything that is not required to create value for the customer/client or end-user. This is primarily process waste with some physical waste. The fact that much of this waste is common to many projects suggests that there are imperfect systems and structural arrangements that support and/or encourage wasteful activities. To say that waste is created due to human error is unhelpful; blame arguably fails to facilitate learning to 'do better' and similarly fails to lead us towards effective methods of reduction or prevention. As Dr Deming taught us: '94\% of troubles and failures are attributed to the system (responsibility of management), $6 \%$ are due to special cases (such as human mistake)' (Deming, 1984, p. 315). Human behaviour is always influenced by the environment in which it takes place (i.e. broader organisational system or institutional environment). Without a deep understanding of the economic, social and environmental issues contributing to poor decisionmaking, it is very likely that similar flawed or risky decisions will recur. For this reason, Levensen (2011) emphasises that: 'Without changing the environment, human error cannot be reduced for long. We design systems in which human error is inevitable and then blame the human and not the system design' (p. 61).

The UK Government has recently created a set of challenging construction targets for 2025 (HM Government, 2013). These include a 50\% faster delivery, $50 \%$ lower emissions, and a 33\% reduction of clients' capital costs - business as usual won't meet this target. There is no doubt that eliminating (process and physical) waste from construction design and delivery is a necessary step towards achieving these goals. There is also no doubt that the adoption of lean production theories into construction has helped scholars and practitioners to understand and identify many of the causes and origins of waste in construction projects, in particular at the project delivery (production) phase. However, the prevailing understanding of waste, arguably, encourages the improvement of current processes rather than fundamental system redesign. Obtaining a better understanding and conceptualisation of waste in construction is therefore becoming more crucial to prepare the industry for the radical change demanded.

\section{Conceptualization of Waste in Construction}

The formal adaptation and transfer of the new production philosophies into construction projects has been ongoing since the early 1990's (Koskela, 1992). These philosophies were characterised as "lean" from the study of Toyota (Krafcik, 1988), and the term 'Lean Construction' rose to prominence with the formation of the International 
Figure 1. Analysis and examples of waste in construction. Proportions based on studies by Diekmann et al. (2004) in the US and unpublished studies in the UK by Cameron Orr, AWD and Construction excellence as cited by Mossman (2009). Diagram adopted and modified from Mossman (2009)

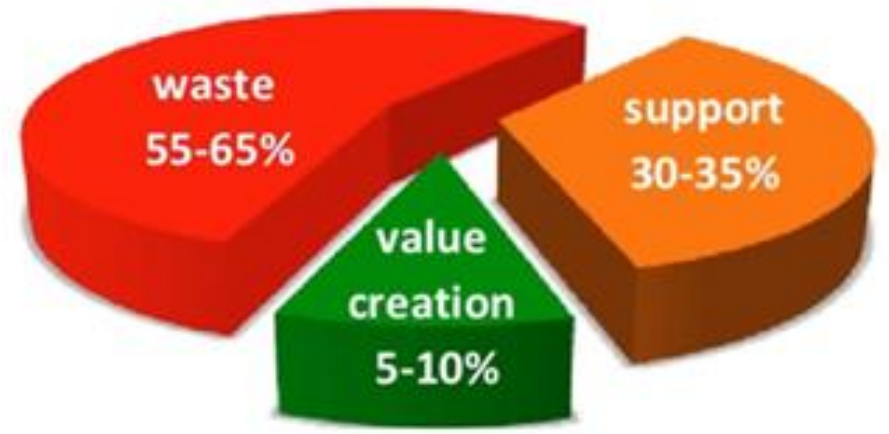

e.g.
Accidents,
Delay, waiting, Rework
Over-ordered materials
Damaged materials
Multiple handling of
materials
Making-Do
Poor payment systems
Duplicate insurance cover
Settling disputes after PC
Tendering
Procuring services on cost

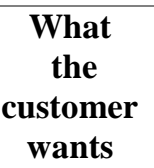

f materials

Making-Do

Poor payment systems

Duplicate insurance cover

Tendering

Procuring services on cost
What we have to do to

enable us to create what the

customer wants

e.g.

Procurement

Taxes

Insurance

Logistics

Accounting

Cost estimating

Commercial management for clarification see:

Zimina \& Pasquire (2011)
Group for Lean Construction ${ }^{1}$ in 1993 . The concept of lean was formally recommended to the UK construction industry by a Government report (Egan, 1998). Traditionally, the term 'waste in construction' is usually limited or intuitively linked to physical (material) waste. The concept of material waste in construction has been widely addressed but the widened understanding introduced by the seven process wastes identified in the Toyota Production System (TPS) (Ohno, 1988) has struggled to be transferred. Process waste is directly associated with executing tasks and conforms to the current understanding of project management as 'a specific set of operations designed to accomplish a singular goal' (Project Management Institute ${ }^{2}$ ). In this way, production is defined as transforming resources towards the

${ }^{1}$ www.iglc.net finished product or project and waste can be seen as the inefficient use of resources in the execution of tasks. The disadvantage of this understanding of waste is that it drives the improvement of current processes rather than radical new system design.

Koskela (2000) advances the definition of lean production to the combination of transformation tasks $(\mathrm{T})$, flow $(\mathrm{F})$ and value creation $(\mathrm{V})$. This definition of production as TFV creates two additional dimensions to the conceptualisation of waste as the inefficient use of resources in tasks. The first additional TFV dimension, flow (F), reveals the interdependency of activities across the whole project process. The consideration of flow brings the supply chain and the logistics of getting resources to the point of transformation into focus. Elevating flow to a project production driver also

${ }^{2}$ www.pmi.org 
alters the classification of process waste within tasks. For example, waiting within one task may now be necessary to expedite tasks downstream this waiting is therefore no longer a waste and results in one task being sub-optimised in order to optimise the project. Consequently the pursuit of waste within transformation activities can itself become a cause of waste if it disrupts flow. Erratic and disrupted flow of processes provide further sources likely to cause waste recognised within TPS in two ways - the unevenness of workflow (Mura) and the related concept of the overburden of capacity (Muri) (Liker, 2004).

The second additional TFV dimension is created by considering value creation (V) and brings the customer into focus. The construction sector typically identifies clients and more recently users and stakeholders - the term customer is not commonly used. However, the inclusion of value creation into project production moves the conceptualisation of waste towards identifying what causes value-loss and questions from whose perspective. This conceptualisation will vary from project to project and from customer to customer meaning the understanding of what constitutes value and how it is created becomes an important part of the design of the project production system (delivery including logistics, design and procurement) and the project product (the physical facility or asset created and what it achieves). One aspect of this conceptualisation is the consideration of the organisational, commercial and institutional environments that surround the design and delivery of construction projects. It is this aspect that leads to the primary research question:

\section{'Is there anything in the commercial and institutional environments surrounding construction that is blocking radical new production system design and therefore pinning the prevailing wasteful system in place?'}

The understanding of value and value loss (or waste) within these wider organisational, commercial and institutional environments is more difficult to determine not least because it requires a critical evaluation of the activities of different professions, for example lawyers, accountants, human resource managers, quantity surveyors to name a few. These environments and the professions within them also exhibit varying cultures, structures, systems and behaviours. Such an evaluation also needs to draw upon theory from disciplines outside both construction and manufacturing such as economics, law and sociology if it is to begin to explain the coherence and yet wastefulness of the current approaches to construction projects.

A contemporary study by Sarhan et al. (2017) reviewed the governance problems confronting clients and decision makers in construction procurement through the lens of Transaction Cost Economics. Their work led to novel explanations so as to why wasteful procurement practices persist, through an economic perspective. However, this study argues that an institutional perspective has the potential to add useful insights. Institutional theory gives significant consideration to context. It could also help to reveal the underlying fundamental paradigms that influence early project decisions and thus shape project performance and outcomes.

An empirical study by Wearne (2014) reviewed the problems of project management as reported by 1,879 individuals employed in the construction, manufacturing, process, and service industries in North-West Europe over 23 years. Interestingly when reviewing the data collected, the same categories of problems appeared to remain the main concern of project management. In an attempt to find answers so as to why many categories of project management problems persist, the analysis of his study reported that:

"More than $75 \%$ of the problems reported
by the participants are due to institutional
practices within organizations rather than
inherent in their projects. Many of these
problems of project management could
therefore be avoided, or at least reduced by
early attention to their causes. As a result
much of what is called "fire- fighting" in
project management-urgent actions on
problems that should not have been
allowed to occur-could be prevented"
(Wearne, 2014, p. 72 ).

"More than 75\% of the problems reported by the participants are due to institutional practices within organizations rather than inherent in their projects. Many of these problems of project management could therefore be avoided, or at least reduced by early attention to their causes. As a result much of what is called "fire-fighting" in project management-urgent actions on problems that should not have been (Wearne, 2014, p. 72) 
The findings of Wearne's (2014) empirical study support recent arguments for improvement in the "front end" decisions on project objectives, plans and governance arrangements (for example, see Edkins et al., 2012). This reinforces the need to investigate the institutional factors that influence early-project decisions and condition project procurement and governance arrangements. In the construction management literature, there are very few, if any, studies that have sought to explore the relationship between institutional factors influencing construction procurement choices and practices, and waste in construction projects. Therefore, this study examines the current commercial and institutional arrangement within construction procurement and attempts to analyse them through the lens of Institutional theory. The study starts by providing a brief overview of the concept of waste-reduction in construction. Following this, the study illustrates the significance of conceptualising construction procurement systems as institutional arrangements. Next, the study reviews behavioural explanations provided by Institutional theory of organisational studies. Subsequently, the study demonstrates how the neoinstitutional theory, a branch of organizational sociology, has the potential to be used as an analytical lens to deliver a more explicit theory of waste relating cause and effect within the wider aspects of construction procurement systems and relationships. The term 'waste' is almost always synonymous with physical waste (i.e. on-site material waste). However, throughout the following sections of this paper, the term 'waste' refers to the wider conceptualisation of waste as summarised above.

\section{Literature Review Methodology}

This study hopes to shed light on a source of waste hitherto unacknowledged in construction. This, therefore, requires an in-depth review of selected relevant literature, with the intension of searching for latent themes (Braun and Clarke, 2006). This interpretative work entails a thorough review of the underlying ideas, assumptions, and conceptualisations informing the content of the data. For this reason, a generic purposive sampling strategy (Bryman, 2012) was adopted for literature review. This strategy is not driven by the statistical imperative of including every available study. Instead, it puts the research questions under investigation at the forefront of sampling considerations (Bryman, 2012). According to Doyle (2003, p. 326), a purposive sample is more appropriate than an exhaustive one, when the aim is explanation rather than prediction. Through this approach, the researcher decides what needs to be known, and deliberately chooses suitable literature which can potentially provide the most relevant information and have the largest impact on the enhancement of knowledge (Patton, 2015, p.276). Based on these considerations, the study targeted peer-reviewed papers published by top journals using electronic search engines (e.g. University's Library OneSearch and Google Scholar) and handsearching of peer-reviewed papers published by proceedings of the Annual Conference of the International Group for Lean Construction (IGLC). The main keywords and topics that were searched for and reviewed included: waste-minimisation in construction, wasteful attitudes and behaviours in construction projects, opportunistic practices, omission errors, conflicts and disputes, relationship between procurement and value loss, hidden transaction costs in construction projects, barriers to partnering, barriers to relational forms of contracting, barriers to lean and integrated project delivery, and changing roles of clients and professional service providers. As a result of this effort, 35 waste-related studies and 76 construction procurement and contractual related articles, ranging from 1994 to 2017, were identified and thoroughly reviewed. When qualitatively analysing the articles, a table of information, that categorises information extracted from each paper, was created to help the authors with organising their thoughts (See Appendix 1).

\section{The Concept of Waste- Reduction in Construction}

The concept of waste-reduction has been fundamentally used as a key driver for improvement in the manufacturing industry, and arguably led to great achievements; but it has not been as prevalent in construction economics or 
management (Koskela and Ballard, 2012; Koskela et al., 2012; Bølviken and Koskela, 2016). Research efforts aimed at understanding waste are relatively limited when compared to other topics in construction, and many waste-related studies continue to focus on the causes rather than the root causes. Two subsequent systematic literature reviews on empirical studies that relate to wasteminimisation in construction (Viana et al., 2012; Formoso et al., 2015) revealed that research is broadly focused on addressing three different categories of waste:

1. Construction material waste (physical waste);

2. Specific sorts of waste (such as accidents and rework).

3. Non value-adding activities (process waste);

Many studies in construction literature have concentrated on 'waste-management' strategies and implementation efforts on construction project sites (for example, Peng et al., 1997; Mcdonald and Smithers, 1998; Lawson et al., 2001). These studies have broadly focused on identifying and assessing strategies for re-using and recycling construction material waste, waste-quantification, waste management mapping to help with the handling of on-site waste, investigating the impact of legislation on waste management practices, suggesting improvements in on-site waste management practices, and developing on-site waste auditing and assessment tools (Osmani, 2012). The current approaches to research in the field of construction waste-minimisation are mainly focused on designing out waste (e.g. Keys et al., 2000); waste minimisation guides for architects and designers (e.g. WRAP, 2009); attitudes, perceptions and behavioural factors towards construction waste minimisation (e.g. Osmani et al., 2008; Begum et al., 2009); the need for improved supply chain integration (e.g. Dainty and Brooke, 2004), and procurement waste minimisation strategies (Gamage et al, 2009).

There are also some other research studies that have focused on specific types of waste such as: rework and design error reduction (e.g. Busby and Hughes, 2004; Love et al., 2009, 2011a, 2013; Feng and Tommelein, 2009) knowledge flow and integration in different construction working environments (e.g. Ruan et al., 2012), designing for construction worker safety (e.g. Toole and Gambatese, 2008), reducing waste by appropriate coordination mechanisms (Sandberg and Bildsten, 2011), and project disputes causations (Love et al., 2011b; Mitropoulos and Howell, 2001). However, most of the studies that have investigated process waste and non-value adding activities have been undertaken by members of the lean construction community. There are many general classifications of process waste as defined in lean thinking. For example, they include Tachii Ohno's seven wastes: transportation, inventory, motion, waiting, overproduction, over-processing, and defects (Ohno 1988, pp. 19-20). In addition, the waste of human potential - e.g. 'Not speaking, not listening' by Macomber \& Howel (2004), and the 'Making-do' waste presented by Koskela (2004) is included within this category.

An overall analysis of waste-related literature in construction reveals five critical issues. First, researchers have gradually shifted their attention and studies from a mere focus on wastemanagement strategies that have mainly been concerned with the consequences of waste, to the promotion of waste-minimisation strategies, as a more sustainable approach that eliminates or reduces construction material waste at its source. Secondly, most of these waste-minimisation approaches, if not all, were directed towards finding means for reducing construction material waste (physical waste) as opposed to process waste. Other important issues such as time waste and value creation are much less explicitly explored.

Thirdly, there is no doubt that many of the problems that lead to the occurrence of waste in construction are strongly related to lean theories adopted in production management. However, it can still be argued that waste is created primarily from project-organisational and contractual problems (Williamson, 1991, pp.78-79); and as such, a focus on waste reduction in site-based production alone would be insufficient. As emphasised by Matthews et al. (2003), it is difficult to maximise value and minimise waste at the project level if the prevailing contractual structure hinders coordination, constrains collaboration and innovation, and sub-optimises performance and 
goals. Similarly, this study argues that procurement systems, as institutional arrangements, are designed to assign liabilities and authorities to people and organizations (Love et al., 1998) at the project and programme levels; and thus structure the borders that shape 'the play of the game' (Williamson, 2000). From a production management perspective, organisation and contracts are essential parts of the production system design; and thus there is no doubt that poorly aligned (imperfect) organisational and institutional arrangements may cause waste and impact on project outcomes (Koskela and Ballard, 2012). Fourthly, a small but growing number of studies have attempted to investigate the influence of procurement processes on the generation of waste in construction projects (e.g. Jaques, 2000; Gamage et al., 2009). However all of these studies have only focused on the relationship between different procurement systems and the generation of construction material waste.

Finally, very limited, if any, waste-related studies have devoted attention to exploring performanceshaping mechanisms (i.e. systems and structural arrangements), as well as the institutional context in which human actions and decisions are constituted. In the construction management literature, there are hardly any studies that have sought to investigate the role played by institutional processes, within the construction procurement context, in embedding waste in construction projects. Waste here can be in the form of monetary, time or effort and can pre or post contract stages.

\section{The Construction Procurement Context}

\section{Construction Procurement Systems}

A common theme of construction literature is the proliferation of definitions of a procurement system (See for e.g. Sharif and Morledge, 1994; Love et al., 1998; Masterman, 2002; Watermeyer, 2012). Both terms: 'contractual arrangement' and 'procurement system' are often used synonymously (Love et al., 1998). Similarly, procurement approaches and additional contract price provisions (e.g. lump sum, guaranteed maximum price, target cost, cost plus) are also commonly regarded as closely related (Oyegoke et al., 2009). Interestingly, a study by Tookey et al. (2001) found that, in industrial practice, clients usually make amendments to mitigate risk and add usability to rigidly prescribed procurement systems that are imposed, in their view, by researchers and consultants when classifying procurement routes. For convenience, the definition adopted here is that a construction procurement system is a 'projectorganisation system that arranges and governs the way that the parties involved can compete and/or cooperate in order to achieve their agreed programme and project goals'. Inspired by Masterman's (2002) forth-fold of procurement methods, Love et al's (1998) categorization of building procurement systems, Kumrasawy and Dissanayaka's (1998) hierarchy or procurement options, and Watermeyer's (2011) framework for developing a construction procurement strategy, this study further conceptualises major construction procurement arrangements as shown in Figure 2, and Table 1 below.

\section{Construction Procurement Subsystems and Options}

Procurement subsystems or/and procedures are identical terms that are commonly used in literature. Previous studies have integrated specific procurement sub-systems to their hierarchy of procurement systems, when investigating the relationship between procurement systems, project parameters, and certain aspects of projectperformance such as: time, cost, quality, work environment, and innovation (Kumaraswamy and Dissanayaka, 1998; Love, 2002; Eriksson and Laan, 2007; Eriksson and Westerberg, 2011). For example, the main procurement sub-systems conceptualised by Kumaraswamy and Dissanayaka (1998) are: work packages; functional groupings (i.e. separated, integrated and management-led); payment modalities; standard sets of contract forms or conditions; and selection methodologies. Similarly, Watermeyer (2012) suggested that procurement and contracting arrangements comprise: procurement selection strategy; 
Figure 2: Major construction procurement systems and sub-systems

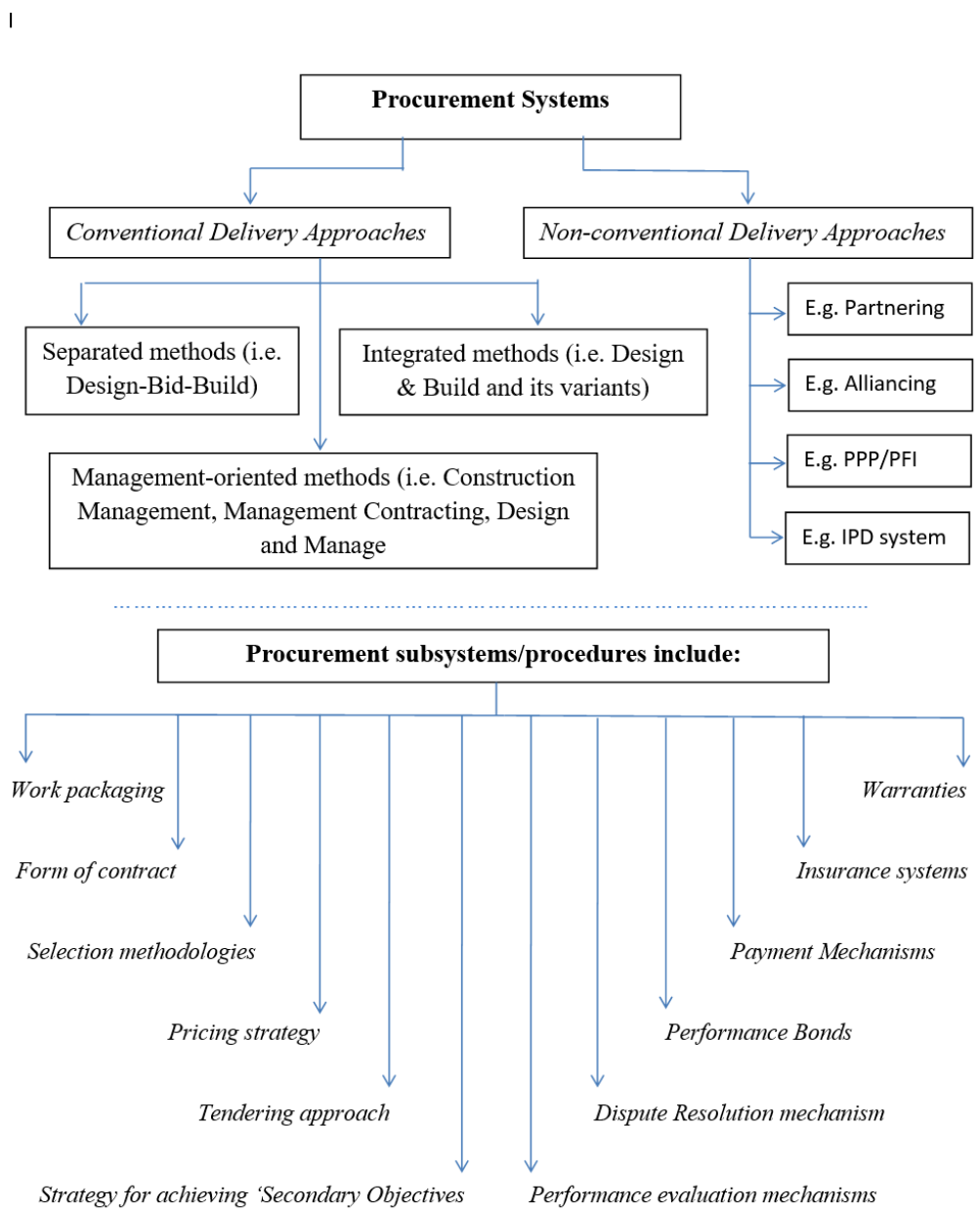

procurement evaluation strategy; contracting strategy (functional groupings); pricing strategy; and form of contract.

In a conceptual study by Eriksson and Westerberg (2011) which developed a hypothetical procurement framework that examines how various procurement-related factors affect project performance criteria, procurement procedures at the buying stage were divided into three categories according to their relation to: competition, coopetition and cooperation. These procurement procedures consisted of: design; tendering; bid evaluation, subcontractor selection; payment; use of collaborative tools; and performance evaluation. Thus, for instance, subcontractors' selectiondecisions made by either the contractor or the client would be related to competitive procurement

procedures; joint selection with single responsibility would be a co-opetitive procedure; while joint selection with shared responsibilities would be regarded as cooperative.

Compellingly, very limited studies in construction management have explicitly considered and integrated, as part of their hierarchy of procurement systems, other critical procurement subsystems such as: insurance arrangements, bonds, collateral warranties, and alternative dispute resolution mechanisms, despite their significant importance and influence on project-teamwork performance. Building on the work of Wordley (1991); Kumaraswamy and Dissanayaka (1998), Love et al. (1998); Hughes et al (2000); Sherif and kaka (2003); Eriksson and Laan (2007); Ghassemi and Becerik-Gerber (2011); Masterman (2011), 
Table 1: Major options available within construction procurement subsystems

\begin{tabular}{|c|c|}
\hline $\begin{array}{l}\text { Procurement } \\
\text { subsystem } \\
\text { /Procedure }\end{array}$ & Possible Options \\
\hline Work packaging & $\begin{array}{l}\text { - Break down based on contract value (e.g. large packaging to be employed for the } \\
\text { purpose of high price competition, or small packaging if specialist expertise is } \\
\text { required) } \\
\text { - Divisions based on geographical divisions or functional and disciplinary divisions } \\
\text { of contracts } \\
\text { - Design based on sequence or interdependence of activities } \\
\text { - Design based on Project risks and the allocation of responsibilities, or project needs }\end{array}$ \\
\hline Form of contracts & $\begin{array}{l}\text { - Standard un-amended set of contract forms and conditions from recognised bodies } \\
\text { (e.g. FIDIC, NEC3, ICE, JCT, contracts) } \\
\text { - Amended standard forms of contract which include special conditions of contract } \\
\text { (e.g. special risk transfer/allocation, length of guarantee and additional insurance) } \\
\text { - Multi-party agreement forms of contract (e.g. PPC2000) } \\
\text { - Discrete/Bespoke contracts (custom-made) }\end{array}$ \\
\hline $\begin{array}{l}\text { Selection } \\
\text { methodologies } \\
\text { (Bid-evaluations) }\end{array}$ & $\begin{array}{l}\text { - High weight on tender price } \\
\text { - Equal weight on price and soft parameters } \\
\text { - High weight on soft parameters (e.g. competence, reputation, capacity, } \\
\text { collaborative-ability, and experience) }\end{array}$ \\
\hline $\begin{array}{l}\text { Payment } \\
\text { mechanism }\end{array}$ & $\begin{array}{l}\text { - } \text { Advanced payments } \\
\text { - } \text { Milestone payments } \\
\text { - Interim payments (e.g. Monthly payments) } \\
\text { - } \quad \text { Stage payments } \\
\text { - Incentive/disincentive payments } \\
\text { - Shared gain/pain arrangements/Target cost }\end{array}$ \\
\hline Insurance systems & $\begin{array}{l}\text { - } \quad \text { Traditional insurance arrangements; } \\
\text { - } \quad \text { Single project-insurance option }\end{array}$ \\
\hline Warranties & $\begin{array}{ll}\text { - } & \text { Collateral warranties; or } \\
\text { - } & \text { latent defect insurance }\end{array}$ \\
\hline $\begin{array}{l}\text { Tendering } \\
\text { approach }\end{array}$ & $\begin{array}{l}\text { - Competitive open bid procedures with or without post-qualifications (one or two } \\
\text { stage tendering); } \\
\text { - Selected- limited bid invitation - with or without pre-qualifications; (one or two- } \\
\text { stage tendering) } \\
\text { - } \quad \text { Direct negotiation with one preferred supplier (no tender) }\end{array}$ \\
\hline Pricing strategy & $\begin{array}{l}\text { - Price-based (e.g. Lump sum; Guaranteed maximum price; Bills of quantities; Price } \\
\text { list/schedule; Activity-based scheduling) } \\
\text { - } \quad \text { Cost-based (e.g. cost-reimbursement; Target cost; and Target value design) } \\
\text { - } \quad \text { Mixed }\end{array}$ \\
\hline $\begin{array}{l}\text { Performance } \\
\text { evaluation } \\
\text { mechanisms }\end{array}$ & $\begin{array}{l}\text { - Output control by client - inspection of the outcome } \\
\text { - Process control by client - ongoing monitoring } \\
\text { - Social control - Self-control by contractor }\end{array}$ \\
\hline
\end{tabular}


Table 1 (Continued): Major options available within construction procurement subsystems

\begin{tabular}{|c|c|}
\hline $\begin{array}{l}\text { Strategy for } \\
\text { achieving } \\
\text { 'Secondary } \\
\text { Objectives' } \\
\text { (e.g. promoting } \\
\text { sustainability, } \\
\text { enhancing health } \\
\text { and safety } \\
\text { performance } \\
\text { beyond statutory } \\
\text { requirements, and } \\
\text { poverty } \\
\text { alleviation) }\end{array}$ & $\begin{array}{l}\text { - Through the use of incentives that are provided in the form of tender evaluation } \\
\text { points } \\
\text { - Through financial incentives for attaining key performance indicators } \\
\text { - Via contractual obligations and mandatory subcontracting requirements }\end{array}$ \\
\hline $\begin{array}{l}\text { Dispute resolution } \\
\text { mechanisms } \\
(D R M)\end{array}$ & $\begin{array}{l}\text { - Conventional DRMs (i.e. litigation, arbitration, adjudication) } \\
\text { - Alternative DRMs (e.g. Mediation, conciliation, early neutral evaluation, } \\
\text { Partnering) }\end{array}$ \\
\hline $\begin{array}{l}\text { Bondings } \\
\text { Safeguarding } \\
\text { approaches }\end{array}$ & $\begin{array}{l}\text { - } \text { Performance/Surety bonds } \\
\text { - } \text { Bank Guarantees } \\
\text { - Standby letters of credit } \\
\text { - } \text { Cash retentions } \\
\text { - Nont company guarantee } \\
\text { qualifications, direct negotiation, single project insurance and } \\
\text { collaborative/relation-based delivery approaches }\end{array}$ \\
\hline
\end{tabular}

Eriksson and Westerberg (2011); Mante et al. (2012); Ndekugri et al. (2013); and Pasquire et al., (2015), Table 1, provides the major options available within procurement sub-systems, as conceptualised within this study.

There is no doubt that the deployment of efficient procurement arrangements (i.e. procurement systems, sub-systems and options) may increase the likelihoods of 'project success' and overall client satisfaction in a particular project context (Kumaraswamy and Dissanayak, 1998). However, in order to optimise the whole, it is important to consider the influence of the interactions between the sub-systems on the output of the main procurement system (Kumaraswamy and Dissanayak, 1998). It is also critical to ensure the compatibility of the chosen procurement options from within each sub-system with the selected project delivery system, client and project needs, and other contextual conditions that bear on the project (Kumaraswamy and Dissanayak, 1998). For instance, it may be unsuitable to choose a cost- reimbursement pricing option for a traditionally procured project (Love et al., 1998). Similarly, it would be inefficient to adapt a bid evaluation strategy based on lowest tender price for the selection of project team members of a partnering project (Eriksson et al., 2008). Thus, it is suggested that procurement arrangements should be crafted to support production system requirements and improve flow processes, rather than being based on cost and risk-averse considerations that may lead to sub-optimisation (Sarhan et al., 2017). The premise here is based on 'optimising the whole' rather than 'optimising the parts'.

Based on these arguments, it is thus ironic how that an empirical survey (Zaghloul and Hartman, 2003), that was conducted in the Canadian and the United States construction industries, revealed that inappropriate risk allocation through disclaimer (exculpatory) clauses in contracts is still the general traditional practice in the construction industry; and that their use is prevalent to an extent that they continue to be utilized in some of the newer contractual agreements such as 
partnering/alliances. Similarly, it is interesting that the clients of many projects that have been procured using an integrated project delivery (IPD) system still rely on the use of performance/surety bonds and traditional insurance arrangements, despite the latter in particular being identified by leading industry professionals in the US as one of the biggest worries for the adoption of IPD to its full capacity (Kent, and Becerik-Gerber, 2010; Ghassemi and Becerik-Gerber, 2011). That is because it was found that traditional insurance products impose liability issues on each projectparty separately and thus make collaboration complicated. The same has been asserted by expert construction professionals in the UK who suggested that conventional arrangements for providing insurance cover add unnecessary costs to constructions projects, and can also obstruct collaboration between supply chains (Ndekugri et al., 2013). According to Mossman et al. (2010, p. 11)

\section{"If each party to a relational agreement is required to have its own insurance and there is a claim during design or construction, an insurance company could force parties to sue one another in order to trigger insurance coverage, threatening relationships".}

These examples suggest the existence of serious power disparities within the construction market place; this in turn allows actors with power, and who may have vested interests for the wide-spread use of some imperfect procurement arrangements, to dictate the rules of the game - the way we do business. Winch (2000a), suggested a number of different factors, yet often working in combination, that could allow some actors in a business system to become relatively powerful compared to others. These were identified by him as those possessing the following capabilities:

- Ability to solve complex problems for the client - e.g. the traditional role of the architect and the consultant engineer in the British system which provides them with the privilege to solve complex problems for the client through the briefing process.
- The blessing of the state (e.g. statutory protection) - For instance, in many countries (e.g. France and Germany) only the architect can apply for building permissions.

- Ability to manage risk for the client - This includes control actors, such as the quantity surveyor, in the UK, whose role was developed to mediate the power of the general contractor on behalf of the client.

\section{The Significance of Procurement as Institutional Arrangements}

Construction business systems are regarded as institutions (Winch, 2000a\&b; Sha, 2004) that are created in countries to specify 'the rules of the game', and regulate the relations and interactions between the different parties involved in the industry. The evolution of these business systems are path dependent and also heavily reliant on the cultural and regulative context within each country (Sha, 2004; Matos-Castano et al., 2014). In other words, the national context leads to the formation of specific business systems which in turn influence the orientation, strategies and performance of individual firms in nationally distinctive ways (Winch, 2000a). Similarly, this study argues that procurement systems, as institutional arrangements, are designed to assign liabilities and authorities to people and organizations (Love et al., 1998) at the programme and project levels; and thus structure the boarders that shape 'the play of the game' (Williamson, 2000). Inappropriate procurement arrangements may lead to time and cost overruns, adversarial relationships between project parties, and ultimately the failure of projects (Kumaraswamy and Dissanayaka, 1998; Mante et al., 2012; Watermeyer, 2012). Thus, there is a wide agreement among scholars and many clients on the fact that getting the construction procurement context right is central to project success (Latham, 1994; Love et al., 1998; Tookey et al., 2001; Eriksson and Laan, 2007; Osipova and Eriksson, 2011).

The construction industry has, over a long period, been subject to substantial criticism for its opportunistic relationships, with conflicts and disputes, and lack of trust, collaboration and 
customer focus often cited as significant amongst its various shortcomings (Egan; 1998; Rooke et al., 2003; Eriksson and Laan, 2007; Love et al., 2010). Hence, traditional procurement arrangements (e.g. separated methods) are potential root causes for the opportunism and lack of cooperation that characterise many construction projects (Eriksson and Laan, 2007; Osipova and Eriksson, 2011), the industry has been urged to start using new and less familiar procurement systems (e.g. partnering and alliancing) that are believed to be capable of enhancing collaboration, commitment and trust between project parties (Egan, 1998). However, despite the strong advocacy for the use of partnering and of the potential benefits that it could attain, its implementation in the construction industry generally remains patchy rather than widespread (Phua, 2006; Eriksson et al., 2008). The same applies to other innovative delivery approaches such as the integrated project delivery (IPD) system (Kent and Becerik-Gerber, 2010). It is thus questionable why traditional procurement arrangements still remain very prevalent in the construction industry (RICS, 2004; CIOB, 2010; RIBA, 2013), and have not, yet, been replaced by more collaborative/relation-based procurement arrangements (e.g. partnering and framework agreements) that are deemed to be more efficient. Even when partnering is utilised, the relationship between contractors and subcontractors is often regarded as 'mere ceremony' (Meyer and Rowan, 1977) and aimed at signalling legitimacy to key observers (Greenwood, 2001). Thus, this is a fundamental question since there are substantial trends towards cooperative ways of working as a means for improving project performance and outcomes. A number of theoretical perceptions exist in literature to predict and explain the reasons for the establishment, process and outcomes of several forms of institutional and organisational arrangements. Out of these, three principal theories seem to provide profound conceptual insights:

1. Transaction cost economics (TCE) (see Williamson, 1975, 1985);

2. Resource-dependence Theory (RDT) (see Pfeffer and Salancik, 1978); and

3. Neo-institutional theory of organisational studies (see Meyer and Rowan, 1977; DiMaggio and Powell, 1983; Scott, 2005).
A common conceptual assumption amongst all is that social or economic actors make rational, albeit bounded, and purposive decisions about the types of contractual and organisational arrangements, that they would form or join, depending on what they conceive to be most beneficial (Phua, 2006). However, it is important to realise that not all institutional and organisational arrangements are cost-based (Rindfleisch and Heide, 1997). For instance, the theory of institutional isomorphism (DiMaggio and Powell, 1983), in contrast to TCE and RDT, has established that many organisational arrangements are not necessarily formed based on efficiency considerations only. Instead, some are also formed due to imitation, mere ceremony (Meyer and Rowan, 1977), or the fact that that they are widely shared, disseminated, and taken for granted throughout an organisational field (e.g. the construction industry) (DiMaggio and Powell, 1983).

An empirical survey study of 87 professional construction clients in Sweden was conducted by Eriksson et al., (2008) to identify the critical barriers to partnering; and to analyse the correlations between clients' perceptions of these barriers, and their actual behaviour in the form of procurement procedures. The study found that the clients' desired objective of increasing cooperation between project parties does not affect their procurement procedures. Clients perceive partnering and cooperative arrangements to be significant and beneficial, but still heavily rely on the use of procurement procedures that foster competition and adversarial relationships. The authors offered two possible explanations for these contradictory results. First, that clients may not be aware of how their procurement decisions and procedures may affect their likelihoods of creating a cooperative environment (Eriksson et al., 2008), and thus impact on project performance and outcomes. Secondly, that clients may not be incentivised enough to adapt less familiar procurement arrangements that are potentially more efficient than conventional approaches (Eriksson et al., 2008).

This lack of incentive for the use of partnering or other collaborative modalities (i.e. lean construction) has been attributed by scholars to several factors such as: lack of adequate awareness and understanding and top management 
commitment (Erikkson et al., 2008; Sarhan and Fox, 2013), and the fact that the construction industry operates in a very competitively costdriven environment (Bresnen and Marshall, 2000). This issue could also be linked to the phenomena described by Bresnen and Haslam (1991) as "habituation", which occurs as experienced clients establish a 'close-minded' approach to building, thereby merely utilizing those procurement procedures that are most familiar to them (Love et al., 1998). Additionally, it could be argued that many clients conform to imperfect conventional procurement procedures, due to institutional pressure imposed on them (DiMaggio and Powell, 1983; Sarhan et al., 2017). Most construction clients are inexperienced or one-off procurers of construction projects (Love et al., 2010); and as such, they invariably rely on professional advice from consultants, financiers and legal advisers. These professional advisers may have a vested interest (i.e. social and/or economic motivations) for the wide-spread use of specific procurement arrangements that may be inefficient in comparison to other newer alternatives (Pasquire et al., 2015). Apart from purely economic-based determinants, very few studies in the construction management literature have been conducted to investigate the role played by institutional determinants in predicting the establishment of projectorganisational arrangements, of which partnering as a collaborative procurement system is one. To fill this gap, Phua (2006) carried out a survey study completed by 526 firms covering various industry disciplines in Hong Kong, in order to shed some empirical light on the reason for the apparent limited use of partnering arrangements in the construction industry. More specifically, the study focussed on investigating whether using an institutional framework could help to provide some useful explanations as to when partnering is likely to occur. Compellingly, the findings have shown that institutional forces far outweigh the significance of economic forces in determining whether or not firms will adopt partnering. It was found that none of the financial incentives in terms of increased profitability, competitiveness or likelihood of increased resource acquisition and reallocation had any significant impact on firms' decisions to adopt partnering at all. Instead, the results showed that the majority of construction firms have not adopted partnering as an alternative to traditional procurement methods, due to the lack of strong institutional partnering norms in the industry. According to Phua (2006, p.622):

"Because the benefits or more precisely the
economic and management advantages
that firms could gain from using partnering
are still debatable and difficult to measure,
there is no a priori reason to expect firms
to favour its use over other procurement
methods other than the fact that there are
obvious institutional norms that propel
firms to use it".

The premise of institutional theory is that individual (i.e. persons) and collective (i.e. organisations) social actors are expected to comply with institutional forces imposed on them, because those that conform 'are rewarded through increased legitimacy, resources, and survival capabilities' (Scott, 1987, p. 498). When the same institutional forces continue to exist over time, firms within relatively circumscribed fields that are bounded by shared understandings and mutual dependence (Scott, 2012) become more homogenous (DiMaggio and Powell, 1983); and thus a dominant organisational arrangement, or 'proto-institution' (Lawrence et al., 2002), is likely to occur (Phua, 2006). Thus, as a corollary, it is argued that the extent to which actors are inclined to the use of imperfect procurement arrangements (e.g. traditional procurement systems), that are deemed to be inefficient in comparison to other more innovative and collaborative approaches, is a function of how deeply entrenched the institutional environment is with respect to rules, technologies, norms, beliefs and expectations that are associated with the concerned practices. Having considered the factors that influence the emergence of organisational arrangements; as well as the impact of procurement systems, as institutional arrangements, on project-team performance and outcomes, the focus now shifts to an introduction of institutional theory and subsequently an exploration of neo-institutional theory. 


\section{Background of Institutional Theory}

Institutional theory has a long and complex history dating back to the mid-nineteenth century and incorporates the pioneering insights of seminal scholars of the social sciences such as Max Webber (Scott, 2005). Old institutional arguments relied on notions that 'institutional contexts structure action'. According to Meyer (2008) 'Individuals were seen as creatures of habit groups as controlled by customs and societies as organized around culture' (p. 790). Theories stretched from the economic to political and religious fields, emphasising more organisational or cultural forms of control. However, in general, the nature of institutions and their forms of control over action were always subject to a lack of clarity and consensus in social scientific thinking (Meyer, 2008).

The old institutionalism was encountered by constant debates about free will and determinism; as it saw humans, groups and organisations as naturally embedded entities in broad cultural and structural contexts. In brief, the old institutionalism was marginalised by the rise of the social sciences of modernity, where conceptions were built around notions of society being comprised of empowered, fairly rational, and rather free actors (Meyer, 2008). These actors include individuals, governments, and the organisations created by people and governments. In addition, much of the work focused on institutionalism from these periods was subsumed in the storming advances of neoclassical theory in economics, behaviouralism in political science, and positivism in sociology. Further development by John Meyer and his colleagues at Stanford University led to a significant revival for the ideas of institutionalism from 1977, with the formulation of neo-institutional theory (Scott, 2005; 2008).

\section{Neo-Institutional Theory}

The neo-institutional theory developed in response to specific processes and structures (i.e. causes of structural change in organisations) that were not adequately explained by prevailing rational-actor and contingency theories (DiMaggio and Powell,
1983; Mahalingam and Levitt, 2007). For example, bureaucratic organisations continued to follow rules that in some cases conflicted with the organisations' own goals. The general argument advanced by the foundational work of Meyer and Rowan (1977) was that formal organisational structures reflected institutional forces instead of technological requirements and resource dependencies. They argued that many of the models giving rise to organisations are based on rationalised myths and rule-like frameworks that depend for their efficacy on imitation and the fact that they are widely shared and disseminated.

In brief, conventional neo-institutionalism literature, in replication of the old institutionalism, emphasised the ways by which institutions constrained and directed people (now perceived as bounded, purposive and empowered actors) to behave in certain regular, relatively rational, but homogeneous and expected ways (DiMaggio and Powell, 1983). With more than 30 years of progress since neo-institutional theory penetrated organisational sociology, the theory has been subject to various developments including reformulation of some of its arguments. Next, three significant areas of development, which are most relevant to the study, will be briefly highlighted (for a fuller review, see Scott, 2008).

\section{Institutional Isomorphism}

In the 1970s, when research efforts were focussed on understanding the reasons for variations amongst the kind (i.e. structural features) of organisations, seminal work by DiMaggio and Powell (1983) sought to explain homogeneity of organisations and practices rather than their variations. Their contention was that: "Highly structured organisation fields provide a context in which individual efforts to deal rationally with uncertainty and constraint often lead, in the aggregate, to homogeneity in structure, culture, and output" (p. 144). They described this phenomenon as institutional isomorphic change, which occurs through three mechanisms: 
Table 2. Scott's Typology of Institutional Pillars and Carriers (Scott, 2001)

\begin{tabular}{|l|c|c|c|}
\cline { 2 - 4 } \multicolumn{2}{c|}{} & \multicolumn{3}{c|}{ Pillars } \\
\hline \multicolumn{1}{c|}{ Carriers } & Regulative & Normative & Cultural-Cognitive \\
\hline $\begin{array}{l}\text { Symbolic } \\
\text { Systems }\end{array}$ & Rules, laws & Values, expectations & $\begin{array}{c}\text { Categories, typifications, } \\
\text { schema }\end{array}$ \\
\hline $\begin{array}{l}\text { Relational } \\
\text { Systems }\end{array}$ & Governance \& power systems & $\begin{array}{c}\text { Regimes, authority } \\
\text { systems }\end{array}$ & $\begin{array}{c}\text { Structural isomorphism } \\
\text { identities }\end{array}$ \\
\hline Routines & $\begin{array}{c}\text { Protocols, Standard Operating } \\
\text { Procedures }\end{array}$ & $\begin{array}{c}\text { Jobs, roles, obedience to } \\
\text { duty }\end{array}$ & Scripts \\
\hline Artifacts & $\begin{array}{c}\text { Objects complying with } \\
\text { mandated specifications }\end{array}$ & $\begin{array}{c}\text { Objects meeting } \\
\text { conventions, standards }\end{array}$ & $\begin{array}{c}\text { Objects possessing } \\
\text { symbolic value }\end{array}$ \\
\hline
\end{tabular}

1. 'Coercive isomorphism' that results from political forces and legitimacy issues;

2. 'Mimetic isomorphism' occurring due to standard responses to uncertainty; and

3. 'Normative isomorphism' associated with professionalisation.

Organisational fields can be defined as those independent actors (i.e. persons and organisations), within somewhat circumscribed arenas, that produce similar services or products and constitute a shared culture and social sub-system (Scott, 2008, 2012). The logic for applying work at organisational field levels is that it provides us with a more systematic level of analysis; as attention is shifted from focussing merely on 'organisations in environments' to focussing on the 'organisation of the environment', with particular consideration to organisations as the key players of the field (Scott, 2008).

\section{Institutional Pillars and Carriers}

Institutional theory has been widely employed among social, economic and political sciences to examine systems ranging from micro-interpersonal interactions to macro global frameworks. Despite the fact that the theory had multiple roots; there is a wide consensus that institutions matter (Peng et al., 2009). Nevertheless, social scholars in various ways were adopting the theory, and there seemed to be a crucial need to move from a looser to a tighter conceptualisation. For this reason, iconic sociologist W. Richard Scott provided a comprehensive conceptual schema (see Table 2), based on his extensive survey to institutional literature, that guides directions for pursuing such a theory. Scott defined institutions as: 'regulative, normative, and cultural/cognitive systems and structures that, together with associated activities and resources, provide stability and meaning to social life' (Scott, 2001, p. 48). His aim was not to provide a new integrated theory of institutions, but instead to better enable us to capture both the commonality and the diversity of past and present conceptions of institutional theory (Scott, 2008).

Hence legitimacy is a primary requisite of any stable social order, the three pillars are analytically distinguished to stress that although interrelated, but they work through varying mechanisms and distinctive motives for compliance (Scott, 2012). For instance, a 'regulative' perspective evaluates legitimacy according to the extent that systems operate in conformance to relevant legal or quasilegal requirements. Alternatively, a 'normative' view asserts a moral basis for evaluating legitimacy; while a cultural-cognitive conception refers to the orthodox and taken for granted features of social life that widely shared beliefs within a community make possible (Scott, 2012). 
Table 3. Institutional antecedents of strategic responses (extracted from Oliver, 1991)

\begin{tabular}{|c|c|c|}
\hline $\begin{array}{l}\text { Institutional } \\
\text { Factor }\end{array}$ & Research Question & Predictive Dimensions \\
\hline Cause & $\begin{array}{l}\text { Why is the organisation being } \\
\text { pressurised to conform to institutional } \\
\text { rules or expectations? }\end{array}$ & $\begin{array}{ll}\text { - } & \text { Legitimacy or social fitness; } \\
\text { - } & \text { Efficiency or economic fitness }\end{array}$ \\
\hline Constituents & $\begin{array}{l}\text { Who is asserting the institutional } \\
\text { pressure on the organisation? }\end{array}$ & $\begin{array}{ll}\text { - } & \text { Multiplicity of constituent demands; } \\
\text { - } & \text { Dependency on institutional constituents }\end{array}$ \\
\hline Content & $\begin{array}{l}\text { To what norms or requirements is the } \\
\text { organisation being pressurised to } \\
\text { conform? }\end{array}$ & $\begin{array}{l}\text { - Consistency with organisational goals; } \\
\text { - Discretionary constituents imposed on } \\
\text { the organisation; }\end{array}$ \\
\hline Control & $\begin{array}{l}\text { How or by what means are the } \\
\text { institutional pressures being exerted? }\end{array}$ & $\begin{array}{l}\text { - Legal coercion or enforcement; } \\
\text { - Voluntary diffusion of norms; }\end{array}$ \\
\hline Context & $\begin{array}{l}\text { What is the environmental context within } \\
\text { which institutional pressures are being } \\
\text { exerted? }\end{array}$ & $\begin{array}{ll} & \text { Environmental uncertainty; } \\
\text { - } & \text { Environmental interconnectedness }\end{array}$ \\
\hline
\end{tabular}

\section{Strategic Responses to Institutional Pressure}

Institutional theory pays significant attention to the context. It considers the processes by which structures including rules, norms, and routines become established as authoritative guidelines for social behaviour. Much of the early studies of institutional theory emphasised that organisations and actors, operating within a specific context, were pressurised to conform to the requirements and constraints of their institutional environment (e.g. DiMaggio and Powell, 1983). Organisations' self-interested rewards obtained from conformance to these institutional forces include, for example, legitimacy, enhancing likelihood of survival, social support, stability, access to resources, acceptance in professions, and expedience to avoid questioning (Oliver, 1991). For these reasons, the prevalent language used was one of 'institutional effects', thereby inferring a determinant 'topdown' argument (Scott, 2005).

This unilateral perspective based on obedient organisations defocussed attentions of institutional scholars away from the fact that social structures are continuously modified by the individual and collective actions of social actors. Thus, according to Scott (2008), one of the important advances to the progress of institutional theory is the introduction of agented actors and accordingly the rise of interactive arguments, which suggest that 'institutional processes' can operate in both 'topdown' and 'bottom up' directions. This was important because it allows us to also identify the social actors who held the widely shared beliefs, or were enforcing taken for granted norms (Scott, 2005).

It was the seminal work of Oliver (1991) who affirmed the role of organisational self-interest and active agency within institutional contexts; by cleverly integrating resource-dependence predictions of organisational strategy with the more limited responses to institutional pressures that traditional institutional models provoked. She pointed out that although acquiescence to institutional processes is the most likely response by organisations and their leaders; strategic responses could range from passive to active resistance as follows: acquiescence; compromise; avoid; defy; and manipulate. Accordingly, organisational reactions to institutional pressure towards conformity will depend on five institutional antecedents (Table 3). 
Figure 3: Conceptual model of construction procurement as institutional arrangements

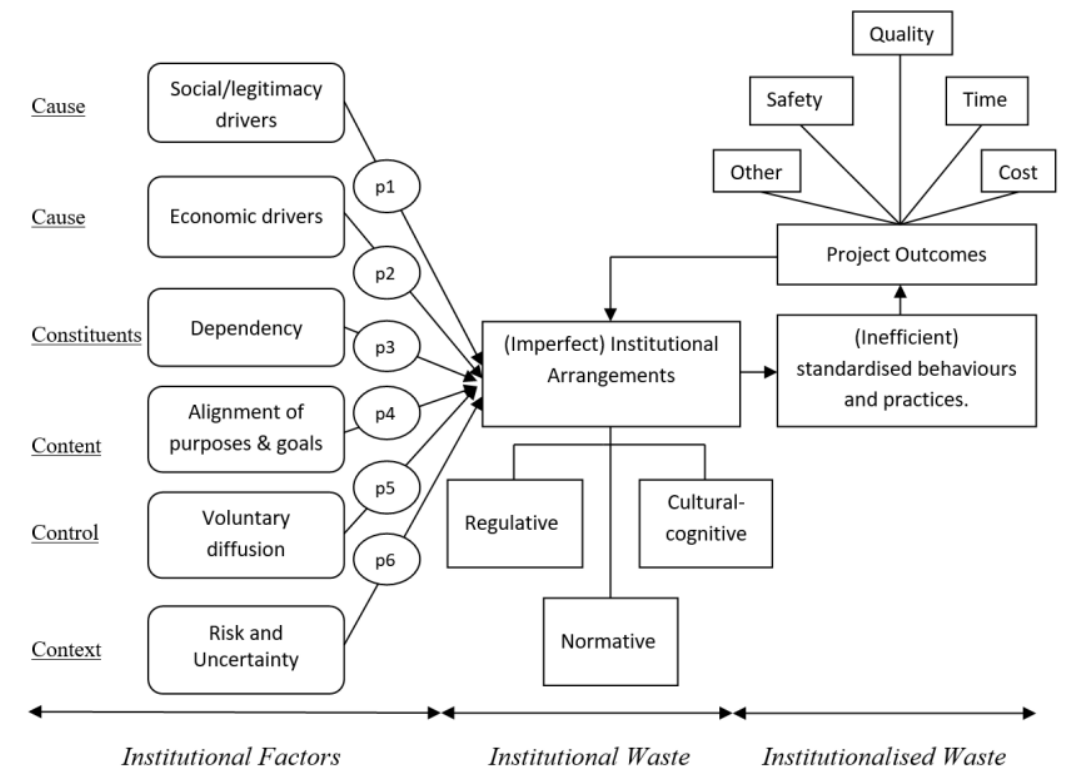

\section{Institutional Waste Within Construction}

Based on this study's hypothesis - that there are systems, structural arrangements and cognitive undergirding assumptions that support and encourage wasteful activities in construction-and building on the seminal studies of DiMaggio and Powell's (1983) institutional isomorphism, Scott's (2001) three pillars of institutionalism, and Oliver's (1991) topology of strategic responses; institutional waste is defined as:

'the regulative, normative, and cognitiveculture institutional processes which support and/or encourage wasteful activities, that the construction industry (organisation field) accedes to in the form of habitual, imitation or compliance; in order to achieve legitimacy, security and survival at the price of production efficiency and effectiveness'.

Effectiveness refers to the extent to which a right target is achieved with resources applied (i.e. value and client satisfaction). Efficiency is the evaluation of how economically the resources are utilised to meet client requirements, based on production flow perspectives (Koskela, 2000). By habitual, here, the study means: adhering to invisible, widely shared and taken for granted norms that have been historically repeated; by imitation: consciously or unconsciously mimicking what other more successful organisations do and strictly following imperfect advice from consulting firms and professional institutions; and by compliance: obeying imperfect institutional requirements. This could include imposing more control in contracts and structural arrangements, for example, as a response to problems of a lack of trust. To elaborate and demonstrate our definition within the context of construction, the following propositions have been formulated (Figure 3).

Proposition 1: The higher the degree of social legitimacy, stability, and/or survival capability conceived by social actors, to be attainable from acquiescence to imperfect institutional pressure, the greater the likelihood of waste to be institutionalised within construction.

An example of this could be the adherence of the construction industry to use short time-frame and price-competitive tendering processes, as a widely shared and taken for granted practice, despite it 
being associated with many flawed risk assumptions and criticised cost estimations (Laryea, 2011). Adding to this, is the use of extensive, time consuming and unnecessarily expensive prequalification procedures (Hughes et al., 2001) in public projects, e.g. questionnaires (PQQ), that may lead to wasteful activities such as cover-pricing. In particular, the use of PQQs for procuring projects below the European Union threshold (approximately $£ 100,000$ ) restrains many SMEs from applying for public contracts (i.e. waste of human potential) and substantially increases tendering costs and time (HM Government, 2013). This also includes the textual complexity and unnecessary formality in contract wordings of some contract conditions (i.e. FIDIC, 1999 and NEC, 1993) that are very difficult to read, and require at least college-level reading skills to correctly interpret them (Rameezdeen and Rajapakse, 2007; Rameezdeen and Rodrigo, 2013). It is important to emphasise here that lawyers and specialist surveyors are not the primary users of a contract; it is the project parties' ability to capture their meaning which is fundamental for contract performance (Rameezdeen and Rodrigo, 2013).

Proposition 2: The higher the degree of financial benefit, protection and guarantee, and/or vested interest rationalised by social actors, to be attainable from conformance to imperfect institutional processes, the greater the likelihood of waste to be institutionalised within construction.

Examples of this include the heavily reliance of construction parties on the deep-rooted practice of using standard forms of contracts (Eriksson and Laan, 2007). These safeguards bring with it lots of formality and rigidity that stifles cooperation and focuses on the individual parties and their responsibilities; thereby driving a distance between project parties and encouraging opportunistic behaviour (Cox and Thompson, 1997; Eriksson et al. 2008). Other examples include the traditional use of disclaimer (exculpatory) clauses in construction contracts (Zaghloul and Hartman, 2003). This unfair risk allocation approach leads to increased costs of projects in the form of unnecessary contingencies and insurances (i.e. cost wastage), restricted bid-competitions (i.e. waste of human potential), and potential disputes (i.e. time waste). Similar imperfect procurement arrangements include the use of high rates of cash retentions on short contracts (Hughes et al., 2000); and requirements for performance bonds that are often disproportionate and may restrict SMEs aiming to bid for public contracts (HM Government, 2013). More obvious examples include architects' and quantity surveyors' biased preferences for the use of traditional lump-sum procurement systems with provisional quantities (Love et al., 1998).

Proposition 3: The higher the degree of dependency of social actors on imperfect institutional processes, the greater the likelihood of waste to be institutionalised within construction.

An example of this could be organisations which depend on obtaining their funding through bank loans, and as a result may pay more attention to their funders' requirements rather than their customers' needs (Chiang and Cheng, 2010). Another example is clients' over-reliance on conventional insurance arrangements which add unnecessary costs to constructions projects and can also obstruct collaboration between supply chains (Ndekugri et al., 2013). This could also be associated with the way that clients' advisors often set the 'rules of the game' (i.e. procurement type and construction periods stated in tenders) and then everyone else has to work within these rules, which could sometimes be dysfunctional. This dilemma is often a result of discrepancies in power that exist among major players in the industry and within project coalitions (Winch, 2000a).

Proposition 4: The higher the degree of consistency of organisational goals and purposes with imperfect institutional pressures and norms, the greater the likelihood of waste to be institutionalised within construction.

For instance, it's not unusual for construction organisations, because of competitive pressure, to rely on making their profits solely through commercial processes and manipulating roles with others, rather than struggling to improve production efficiency (Zimina and Pasquire, 2011b). As an interviewee in a study by Chiang and Cheng (2010) commented, contractors could only 
make profits, in this highly price-competitive industry, if they concentrated their efforts on three issues: (1) procurement of building materials; (2) cash flow management with their downstream supply chain; (3) planning for and application of claims. Thus, this suggests that it important, for further studies, to identify clients' and construction organisations' characteristics, strategies and tactics, that make them more or less obedient to imperfect institutional processes..

Proposition 5: The higher the degree of voluntary diffusion of imperfect institutional rules, routines or norms, the greater the likelihood of waste to be institutionalised within construction.

This is mainly associated with mimetic institutional waste. An example could be the imperfect norms, job duties and responsibilities diffused by professional institutions and trade associations, with which its members are requested to conform. In such cases of very widely taken-for-granted understandings of what constitute genuine practices, it is highly likely that practitioners will conform because it does not occur to them to do otherwise (Oliver, 1991). Labour/trade unions are also powerful actors that influence the culture in the construction industry. They were identified in an empirical study by Eriksson et al. (2008) as industry barriers to change in general, and increased cooperation in specific, due to their conservative and defensive culture that encourages upholding of the status quo. An example of imperfect institutional pressure diffused by trade unions, as identified by Eriksson et al. (2008), was their requirement for fixed piece rates, regardless of time, for blue-collar workers, which in turn undermined collaboration between different crafts. Another example would include decision maker's simply trying what others have found to work, for example traditional procurement, or critical path planning - push system technique (Koskela et al., 2014).

Proposition 6: The higher the degree of environmental uncertainty, the greater the likelihood of waste to be institutionalised within construction.
Environmental uncertainty in the construction industry can include, for e.g., fluctuations in the state of the economy comprised of factors such as inflation, changes to government macroeconomic policies and periods of instability of funding. Under such conditions, it is more likely for organisations to adhere to imperfect institutional regulations, norms \& requirements imposed on them by governmental management, funders, professional association and public media pressure for the sake of survival, legitimacy, and protection from environmental turbulence (Oliver, 1991).

\section{Concluding Discussion}

The construction industry is often regarded as confrontational, risks averse, and lacking trust and capacity for innovation and improvement (Zaghloul and Hartman, 2003; Rooke et al., 2004; Eriksson and Laan, 2007; Eriksson et al., 2008). It has been extensively criticised, in particular, for its short term "hit-and-run" relationships which are focused on win-lose situations. Generally, increased collaboration between project parties, to support production flow, has been argued to be a suitable remedy for many of the industry's problems (Eriksson et al., 2008; Sarhan et al., 2017). Since, the extent of cooperation (and trust) is largely influenced by procurement arrangements and procedures (Sarhan et al., 2017, Eriksson and Laan, 2007); this is considered a key area that requires substantial attention and improvement (Egan, 1998) and which is central to overall client satisfaction and project success (Love et al., 1998; Tookey et al., 2001; Osipova and Eriksson, 2011). A small but emerging number of studies have attempted to investigate the relationship between procurement systems and waste in construction (e.g. Gamage et al., 2009). However, most of these studies, if not all, have limited their attention to material waste as opposed to process waste and value creation. Additionally, very few, if any waste-related studies, have sought to explore the influence of performance shaping mechanisms (i.e. institutional context in which human actions take place and decisions are made) within the construction procurement context.

Hence, Construction business systems are regarded as institutions (Winch, 2000a\&b; Sha, 2004) that 
are created in countries to specify 'the rules of the game', and regulate the relations and interactions between the different parties involved in the industry. As a corollary, this study conceptualises procurement systems as institutional arrangements that are designed to assign liabilities and authorities to people and organizations at the programme and project levels; and thus structure the boarders that shape the play of the game. According to economic institutionalists, there are at least three types of influences that institutions, whether formal (e.g. rules and regulations) or informal (e.g. norms), have on behaviour (Dequesh, 2002, Phua, 2006):

- Constraints on behaviour in the form of rules and regulations and set of procedures to detect deviations from the rules and regulations, and set of moral and ethical norms that define the boarders that confine the way in which the rules and regulations are specified and enforcement is carried out (i.e. restrictive function);

- Influence on perception or reception of reality (ie. informational-cognitive function);

- Influence on end goals that people pursue (i.e motivational or teleological function).

From an economic perspective, it is easy to understand why economic actors are more likely to conform to institutional forces, as this will be based on obvious cost and efficiency-based considerations; and also due to the prevailing 'norms that provide "legitimacy" to a set of rules' (North, 1994, p. 366). However, the social perspective argues that the compliance with institutional processes is not necessarily based on efficiency considerations. Instead, conformance is principally based on social legitimacy drivers (Scott, 2012). The compliance with norms, beliefs and regulations is regarded important, because it allows those who comply with them to gain increased legitimacy, survival capability, social support, stability, access to resources, acceptance in professions, and expedience to avoid questioning (Oliver, 1991, Scott, 2005).

Despite the distinctive differences underpinning each of these two perspectives, an overarching assumption common to both is that people and organisations are seen as rational, purposive and empowered, albeit bounded, actors whose behaviours and decisions are constrained by the influence of the institutional pressure imposed on them (Phua, 2006). Scott (2012) has argued that the concepts employed in contingency and resourcebased studies are relatively limited when compared to neo-institutional theory of social and organisational studies, as they direct main attention to governments and regulatory systems; thereby neglecting the equally important roles played by normative and cultural-cognitive systems. Similarly, the authors of this study believe that institutional concepts used in economic-based studies (e.g. Williamson, 2000), overlook, or at least give less attention to, normative and culturalcognitive systems, that are vital forces affecting the success of construction projects (Scott, 2012). Hence, the construction industry is very labourintensive/oriented, it seems to us therefore that neoinstitutional theory is more suitable and powerful for construction management studies in general, and this study in specific.

The fact that much of the waste produced in construction is common to many projects led to the study's hypothesis that there are imperfect institutional regulations, norms, and cultural cognitive framework assumptions within the construction procurement context, which support and/or encourage wasteful activities. Examples of these include: traditional lump-sum procurement systems based on price-competitive tendering (Winch, 2000b; Love et al., 2011b; Laryea and Hughes, 2008; Mohammed et al., 2011); silo thinking and resistance to change such that existing values and beliefs are not open for questioning (Winch, 2000a; Eriksson et al., 2008); traditional insurance products (Kent and Becerik Gerber, 2010; Ndekugri et al., 2013); textual complexity of standard contracts (Rameezdeen and Rajapakse, 2007; Rameezdeen and Rodrigo, 2013), disclaimer clauses (Zaghloul \& Hartman, 2003; Love et al., 2010); late payments (Poverbs, 2000; Hughes, 2000),); the short-term focus as exemplified by clients' habit of changing suppliers between projects through the frequent use of open bid invitation procedures (Erikkson et al, 2008).

Many of these imperfect procurement arrangements and assumptions are common in construction projects, leading to frequent 
unsatisfactory outcomes. It is thus questionable why conventional procurement systems remain very prevalent, as opposed to newer and more collaborative forms of procurement that are deemed to be more beneficial and efficient. This is a valid fundamental question hence there are substantial trends towards establishing cooperative ways of working as a means for improving project performance and outcomes. Previous research has provided different explanations which helped to partially explain the reason for this contradiction between clients' desires and actions. These included the fact that the construction industry operates in a very competitively cost-driven environment (Bresnen and Marshall, 2000). In a study by Eriksson et al. (2008), it was suggested that clients lack the incentives for the use of partnering due to inadequate awareness and understanding of how their procurement procedures influence their likelihoods of creating a cooperative environment. Other reasons suggested by them included lack of top management commitment and resistance to change. Similarly, Brensen and Haslam (1991) linked this to the "habituation" phenomenon that occurs as experienced clients establish a 'close-minded' approach to building, thereby merely utilizing those procurement procedures that are most familiar to them (Love et al., 1998). Phua (2006) attributed this to the lack of dominating industry norms that advocate the use of partnering (e.g. government policies and guidelines, technologies, beliefs and expectations).

Additionally, it could be argued that many clients conform to imperfect conventional procurement procedures, due to institutional pressure imposed on them (Sarhan et al., 2017). Most of the clients, who procure construction projects, lack experience and may only ever build once or twice (Love et al., 2010). Thus, they invariably rely on taking professional advice from consultants, financiers, and legal advisers. These actors who are relatively powered than other (winch, 2000a), may have a vested interest (i.e. social and/or economic motivations) for the wide-spread use of some imperfect procurement arrangements; thereby dictating the rules of the game - the way we do business (Sarhan et al., 2017). When imperfect procurement (institutional) arrangements prevail they restrict and govern the way that project partners behave and interact, leading to common and repeated unsatisfactory outcomes (see Figure $3)$.

Due to the one-off nature of many construction projects and the short-term focus characterising many construction clients and decision-makers, there are less opportunities for learning from project outcomes. Let alone, that the construction industry, as an organisational field (DiMaggio and Powell, 1983), is particularly characterized by its high levels of complexity and industry specific uncertainties and interdependences (Dubois and Gadde, 2002). Accordingly, this study argues that imperfect institutional forces that surround the construction procurement environment lead to more legitimacy and/or use of risk-averse safeguarding approaches in procurement (Sarhan et al., 2017), which deter attention away from coreefficiency purposes; thereby restricting value creation and possibly decreasing revenues for all project parties. When the same or similar (imperfect) institutional pressures continue over time, isomorphism (DiMaggio and Powell, 1983) will lead to (inefficient) construction procurement arrangements becoming more homogeneous, and as a result, standardised patterns of behaviour and common project outcomes are most likely to occur. These arguments are supported by Winch (2000a) who stressed, albeit through a relatively limited economic insight that:

"Just as patterns of behaviour become
institutionalized so that they act back upon
the actors through the process of
structuration (Giddens, 1984), the rules of
the game come to be seen as given, normal,
the only way to do things. Careers and status
become dependent upon certain rules;
threats to those rules become personal
attacks". (p.90)

Work by Sarhan et al. (2016) discussed the factors influencing the 'Principal-Agent' relationship in construction, demonstrating that institutional forces (i.e. vested interests and bargaining strength of major industry players) can have an influence on shaping procurement practices. Their study used the UK's Highways Agency transformation into Highways England, as a practical example of how construction models and procurement practices 
Table 4. A categorisation of various safeguarding approaches in construction procurement (Sarhan et al., 2017)

\begin{tabular}{|l|l|}
\hline $\begin{array}{l}\text { Prevalent safeguarding approaches based on 'risk } \\
\text { allocation' considerations }\end{array}$ & $\begin{array}{l}\text { Less prevalent safeguarding approaches based } \\
\text { on 'process flow' considerations }\end{array}$ \\
\hline Standard forms of contract & Relational contracting \\
\hline Use of Disclaimer/Exculpatory clauses & Shared risks and rewards \\
\hline Traditional insurance arrangements/products & Single project insurance \\
\hline Collateral warranties & Latent defects insurance \\
\hline
\end{tabular}

often mirror institutional factors. According to them, this transformation and change in the status of the principal has led to change in rules and procurement practices in the UK highways sector. This included, for example, a movement from the deployment of large integrated 'manage and maintain' contracts towards fragmenting contracts in order to secure greater control and visibility of costs.

A subsequent study by Sarhan et al. (2017) identified and critically evaluated a number of imperfect taken for granted safeguarding techniques (Table 4) in construction procurement, which stifle cooperation and entrench wasteful processes across the supply chain and throughout the project. According to them, these imperfect procurement arrangements dominate the management of the project delivery often to the detriment of the project itself; but because there is a belief that interests are safeguarded, clients and decision makers feel they have taken the best course of action. Thus, these imperfect safeguarding practices, based on mal-applied transactional considerations, was described by them as a source of institutionalised waste in construction. They argued that 'self-interest' (as a cultural/cognitive institutional factor) drives opportunism and influences governance approaches, leading to a dichotomy as one organisation seeks to protects its interests from the opportunism of others whist continuing to exploit all opportunities. Interestingly, their study urged us to focus our attention towards institutional factors influencing the choice of imperfect procurement arrangements, as they are the 'root causes' for many of the wastes we encounter at the supplychain level.

This study builds on the work of Sarhan et al. (2016 and 2017) to provide explanations as to how that an imperfect institutional environment can lead to inferior construction procurement arrangements, which may cause transaction and production losses (i.e. waste). In general, increased trustful collaboration between project parties, to support and enhance production flow, is argued to be an appropriate remedy for many of the industry's problems (see e.g. Eriksson et al., 2008; Xue et al., 2010; Sebastian, 2011; Walker et al., 2017). The adoption of collaborative procurement approaches can help to align interests and eliminate much of the waste embedded in construction processes; however, arguably, the prevailing imperfect institutional factors and mind-sets are pinning the wasteful system in place. The conceptual model (Figure 3) and guiding propositions provided in this study could act as a primary step for unpicking the coherence and yet wastefulness of the current construction business models. This approach resonates with Matos-Castano's (2014) assertion that providing an enabling environment for newer and more collaborative construction business and procurement models entails a combination of changing existing institutions relating to project procurement and creating supporting institutions that build trustful collaboration between and among stakeholders, as opposed to merely creating institutions to provide legitimacy to public sector decision makers. 


\section{Conclusions and Further Research}

The prevailing understanding of waste, arguably, encourages the improvement of current processes rather than fundamental system redesign. Obtaining a better understanding and conceptualisation of waste in construction is therefore becoming more crucial to prepare the industry for the radical change demanded. Certainly, one aspect of this conceptualisation is the consideration of the wider institutional, organisational, and commercial environments that surround the design and delivery of construction projects. Institutions influence beliefs, norms and actions; thus they shape performance and outcomes. However, this study found that the concept of institutions is not well established in construction management and economics research, specifically in waste-related literature. An overall analysis of the concept of waste in construction, revealed that very few, if any, studies have sought to consider the influence of the commercial and institutional context on pinning the prevailing wasteful system in place.

This study has offered a novel perspective to the generation and persistence of waste in construction projects by introducing the concept of 'Institutional Waste' within the construction procurement context. The study has also exemplified various taken-for-granted rules, norms and meanings that impede efficiency and improvement efforts in construction. Based on a thorough review of construction-procurement literature, using neoinstitutional theory as an analytical lens, the study stressed that construction procurement arrangements and practices are shaped by institutional structures, beliefs and attitudes as well as project characteristics. The study also demonstrated how that an imperfect institutional environment influences construction procurement arrangements, thereby contributing to the generation of institutionalised wastes in construction projects. Having provided a conceptual framework, the six propositions developed, within this study, lend themselves to empirical testing. The underlying premise of this study is that if we can understand the detailed 'institutional causes' of coherence for the prevailing construction business models and reveal the consequential waste, then the adoption of more efficient and collaborative business and project delivery models may become more widespread.

The scope of this study is limited to commercial buildings, industrial construction and infrastructure projects in the UK. However, with an exception to the varying regulative context within different countries, it could be argued that the construction culture and norms of practice are relatively universal (Rooke et al., 2003). Thus, the concept of 'institutional waste' has the potential to be generalised across the whole construction industry worldwide. Future studies are encouraged to assess the concept's compatibility, relevance and significance to other sectors and industries.

The findings presented in this study provide a theoretical anchor and rationale for future reshaping of the roles and responsibilities of the professions and wider participants involved within the construction sector, in order to increase the production effectiveness of the industry. Future studies are also recommended to gain a better understanding of the clients' and major players' characteristics, strategies and tactics, that make them more or less obedient to imperfect institutional and commercial pressure. In that way, this can help clients and decision makers to be aware of the institutional factors affecting the choice of their procurement procedures, and thus their desired project outcomes. Also, it could enable them to consider the adoption of newer contractual and project-organisational techniques that could be of more value to them.

\section{Acknowledgements}

Special thanks to the anonymous reviewers whose comprehensive feedback and comments have helped to improve the focus and quality of this paper. 


\section{References}

Ancell, D (2005) Reducing costs: a practical application of performance-based specification and transaction cost theories. In: Khosrowshahi, F (Ed.), 21st Annual ARCOM Conference, 7-9 September 2005, SOAS, University of London. Association of Researchers in Construction Management, Vol. 2, 721-729

Barnes, M (1999) Smeaton to Eagon - the Extraordinary History of Civil Engineering Management, Smeaton Lecture, Institution of Civil Engineers

Begum, R. A., Siwar, C., Pereira, J. J., and Jaafar, A. H. (2009) 'Attitude and behavioral factors in waste management in the construction industry of Malaysia', Resources, Conservation and Recycling, 53(6), 321-328

Bresnen, M. and Marshall, N. (2000) 'Partnering in construction: a critical review of issues, problems and dilemmas', Construction Management and Economics, 18, 229-37.

Bresnen, M.J., and Haslam, C.O. (1991) 'Construction industry clients: a survey of their attributes and project management practices', Construction Management and Economics, 9(4), 327- 342.

Busby, J.S. and Hughes, E.J. (2004) 'Projects, pathogens, and incubation periods', International Journal of Project Management, 22, 425-434

CIOB (2010) A report exploring procurement in the construction industry, Chartered Institute of Building

Chiang, Y. and Cheng, E. (2010) 'Construction loans and industry development: the case of

Hong Kong' , Construction Management and Economics, 28(9), 959-969

Chapman, J. (2002) System Failure: Why Governments Must Learn to Think Differently, London: Demos

Cox, A. and Thompson, I. (1997) 'Fit for purpose contractual relations: determining a theoretical framework for construction projects', European Journal of Purchasing and Supply Management, 3(3), 127-135

Dainty, A. and Brooke, R. (2004) 'Towards improved construction waste minimisation: a need for improved supply chain integration?', Structural Survey, 22(1), 20-29

Deming, W. E. (1984) Out of the Crisis, MIT Press, Massachusetts

DiMaggio, P.J., \& Powell, W.W. (1983) 'The iron cage revisited: Institutional isomorphism and collective rationality in organizational fields' , American Sociological Review, 48(2), 147 - 160

Diekmann, J. E, Krewedl, M., Balonick, J., Stewart, T., and Won, S. (2004) Application of Lean
Manufacturing Principles to Construction, Construction Industry Institute, Report No.191

Domingo, N., Osmani, M., and Price, A.D.F. (2009) 'Construction waste minimisation in the UK healthcare industry', In: Dainty, A. (Ed) Procs 25th Annual ARCOM Conference, 7-9 September 2009, Nottingham, UK, Association of Researchers in Construction Management, 1021-30

Dubois and Gadde (2002) ' The construction industry as a loosely coupled system: implications for productivity and innovation', Construction Management and Economics, 20(7), 621-631

Eadie, R., McKeown, C., and Anderson, K. (2013) 'The impact of recession on construction procurement routes', Int. J. Procurement Management, 6(1), 24-36

Egan, J. (1998) Rethinking Construction: Report of the Construction Task Force, London:HMSO.

Eriksson, P. E., Nilsson, T., Atkin, B. (2008) 'Client perceptions of barriers to partnering', Engineering, Construction and Architectural Management, 15(6), $527-539$

Eriksson, P.E. and Laan, A. (2007) 'Procurement effects on trust and control in client-contractor relationships', Engineering, Construction and Architectural Management, 14(4), 387 - 399

Eriksson, P. E., Atkin, B., and Nilsson, T. (2009) 'Overcoming barriers to partnering through cooperative procurement procedures' Engineering, Construction and Architectural Management, 16(6), $598-611$

Eriksson, P. E. and Westerberg, M. (2011) 'Effects of cooperative procurement procedures on construction project performance: A conceptual framework', International Journal of Project Management 29, 197-208

Feng, P. and Tommelein, I. (2009) 'Causes of rework in California hospital design and permitting: augmenting an existing taxonomy', Proceedings for the IGLC-17, Taiwan

Gamage, I.S.W., Osmani, M. and Glass, J. (2009), 'An investigation into the impact of procurement systems on waste generation: the contractors' perspective. In: Dainty, A. (Ed) Procs 25th Annual ARCOM Conference, 7-9 September 2009, Nottingham, UK, Association of Researchers in Construction Management, 1031-40.

Garrison, T. (2013) 'The great construction industry myth', The Garrison Report \#2013-9; available at: http://www.tedgarrison.com/resources/garrisonreport/2013-reports/2013-9-the-great-constructionindustry-myth/ (Date of Access: January 2015)

Ghassemi, R. and Becerik-Gerber, B. (2011) 'Transitioning to integrated project delivery: potential barriers and lessons learned', Lean 
Construction Journal, Lean and integrated project delivery special issue, 32-52

Greenwood, D. (2001) 'Subcontract procurement: are relationships changing?', Construction Management and Economics, 19(1), 5-7

Griffith, A. and King, A. (2003) 'Examining the dynamics of novation from the principal contractor's and architect's perspectives', The Australian Journal of Construction Economics and Building, 3(1), 13-18

HM Government (2013) 'Making public sector procurement more accessible to SMEs', Available at: https://www.gov.uk/; Access date: 06/03/2015.

Hughes, W., Hillebrandt, P., and Murdoch, J. (2000) The impact of contract duration on the cost of cash retention', Construction Management and Economics, 18(1), 11-14,

Hughes, W., Hillebrandt, P., and Murdoch, J. (2000) 'The impact of contract duration on the cost of cash retention', Construction Management and Economics, 18(1), 11-14

Hughes, W., Hillebrandt, P., Lingard, H. and David Greenwood (2001) 'The impact of market and supply configurations on the costs of tendering in the construction industry' , In: CIB World Building Congress, April 2001, Wellington, Australia

Jaques, R. (2000) 'Construction waste generation - The influence of design and procurement', Architectural Science Review, 43(3), 141-146.

Kent, D. C. and Becerik-Gerber, B. (2010) 'Understanding Construction Industry Experience and Attitudes toward Integrated Project Delivery', Journal of Construction Engineering and Management, Vol. 136, No. 8, pp. 815-825

Keys A, Baldwin A and Austin, S. (2000) 'Designing to encourage waste minimisation in the construction industry', Proceedings of CIBSE National Conference, Dublin

Konchar, M. (1997) 'A comparison of United States project delivery systems', Technical Report No. 38, The Pennsylvania State University

Koskela, L. (2000) An Exploration towards a Production Theory and its Application to Construction, Degree of Doctor of Technology, Helsinki University of Technology

Koskela, L. (2004) ' Making-do-- The Eighth Category of Waste' , Proceedings for the IGLC- 12, Elsinore

Koskela, L. and Ballard, G. (2006) 'Should project management be based on theories of economics or production?', Building Research \& Information, 34(2), 154-163

Koskela, L. and Ballard, G. (2012) 'Is production outside management?' Building Research and Information, 40(6), 724-737
Koskela, L., Bolviken, T., and Rooke, J. (2013) ' Which are the Wastes of Construction?', Proceedings for the IGLC-21, Brazil

Koskela, L., Sacks, R. and Rooke, J. (2012) 'A brief history of the concept of waste in production', Proceedings for the IGLC-20, San Diego, USA, 1820, July, 2012

Koskela, L., Howell, G., Pikas, E., and Dave, B. (2014) 'If CPM Is So Bad, Why Have We Been Using It So Long', In:, Kalsaas, B.T., Koskela, L. \& Saurin, T.A., 22nd Annual Conference of the IGLC. Oslo, Norway, 25-27 Jun 2014. pp 27-37.

Kumaraswamy, M. and Dissanayaka, S. (1998) 'Linking procurement systems to project priorities', Building Research \& Information, 26(4), 223-238

Laryea, S. \& Hughes, W. (2008) 'How contractors price risk in bids: theory and practice' , Construction Management and Economics, 26(9), 911-924

Laryea, S. (2011) 'Quality of tender documents: case studies from the UK' , Construction Management and Economics, 29(3), 275-286

Latham, M. (1994), Constructing the Team, HMSO, London

Lawrence, T.B., Hardy, C., and Phillips, N. (2002) 'Institutional effects of interorganizational collaboration: the emergence of proto-institutions', Academy of Management Journal, 45, 281-90.

Lawson, N., Douglas, I., Garvin, S., McGrath, C., Manning, D., and Vetterlein, J. (2001) 'Recycling construction and demolition wastes - a UK perspective', Environmental Management and Health, 12(2), $146-157$

Loosemore, M. \& Tan, C. (2000) 'Occupational stereotypes in the construction industry', Construction Management and Economics, 18:5, 559-566,

Love, P. (2002) 'Influence of project type and procurement method on rework costs in building construction projects', Journal of Construction Engineering and Management, 128(1), 18-28

Love, P.E.D., Edwards, D., and Irani, Z. (2009) ‘ Project pathogens: the anatomy of omission errors in construction and resource engineering projects' , IEEE Transactions on Engineering Management, 56(3), $425-435$

Love, P., Davis, P., Ellis, J., and Cheung, S. (2010) 'A systemic view of dispute causation', International Journal of Managing Projects in Business', 3(4), 661680

Love, P.E.D. and Skitmore, M. (1996) 'Construction project delivery systems: an analysis of selection criteria weighting',, CIB W92 'North meets South' 
Procurement Systems Symposium Proceedings, Durban, South Africa, R.G. Taylor (ed.), pp. 329- 42.

Love, P.E.D., Davis, P., Cheung, S., and Irani, Z. (2011b) 'Causal Discovery and Inference of Project Disputes', IEEE Transactions on Engineering Management, 58(3), 400-411

Love, P.E.D., Edwards, D., Han, S., and Goh, Y. (2011a) 'Design error reduction: toward the effective utilization of building information modelling', Research in Engineering Design, 22(3), 173-187

Love, P., Skitmore, M., and Earl, G. (1998) 'Selecting a suitable procurement method for a building project', Construction Management and Economics, 16(2), 221-233

Love, P.E.D., Lopez, R., and Edwards, D. (2013) 'Reviewing the past to learn in the future: making sense of design errors and failures in construction', Structure and Infrastructure Engineering: Maintenance, Management, Life-Cycle Design and Performance, 9(7), 675-688

Macomber, Hal and Howell, G. (2004) 'Two great wastes in organizations: A typology for addressing the concern for the underutilization of human potential, Proceedings for the IGLC-12, Denmark

Mahalingam, A. and Levitt, E.R. (2007) ' 'Institutional theory as a framework for analyzing conflicts on global projects', Journal of Construction Engineering and Management, 133(7), 517 - 28.

Mante, J., Ndekugri, I., Ankrah., N. and Hammond, F. (2012) 'The influence of procurement methods on dispute resolution mechanism choice in construction' In: Smith, S.D (Ed) Procs 28th Annual ARCOM Conference, 3-5 September 2012, Edinburgh, UK, Association of Researchers in Construction Management, 979-988.

Masterman, J.W.E. (2002) Introduction to Building Procurement Systems, 2nd Edition, Spon Press, London.

Matos-Castaño, J., Mahalingam, A., and Dewulf, G. (2014) 'Unpacking the Path-Dependent Process of Institutional Change for PPPs', Australian Journal of Public Administration, 73(1), 47-66

Matthews, O., Howell, G., and Mitropoulos, P. (2003) 'Aligning the lean organization: a contractual approach', Proceedings of the 11th Annual Conference of the International Group for Lean Construction. Virginia, USA

McDonald, B. and Smithers, M. (1998) 'Implementing a waste management plan during the construction phase of a project: a case study', Construction Management \& Economics, 16(1), 71-78

Meyer, J.W. (2008). 'Reflections on institutional theories of organizations' , In R. Greenwood, C. Oliver, K. Sahlin, \& R. Suddaby (Eds), The sage handbook of organizational institutionalism: 790-81 2. Thousand Oaks, CA: Sage.

Meyer, J.W., \& Rowan, B. (1977) 'Institutionalized organizations: Formal structure as myth and ceremony' , American Journal of Sociology, 83 (2), $340-363$

Mitropoulos, P. and Howell, G. (2001) 'Model for Understanding, Preventing, and Resolving Project Disputes' , Journal of Construction Engineering and Management' , 127(3), 223-231

Mohammaed, K., Khoury, S., and Hafiz, S. (2011) ‘ Contractor' $\mathrm{s}$ decision for bid profit reduction within opportunistic bidding behavior of claims recovery' , International Journal of Project Management, 29, 93 - 107

Moore, D. and Dainty, A. (2001) 'Intra-team boundaries as inhibitors of performance improvement in UK design and build projects: a call for change', Construction Management and Economics, 19(6), 559-562

Mossman, A. (2009) 'Creating value: a sufficient way to eliminate waste in lean design and lean production', Lean Construction Journal, 2009, 13-23.

Mossman, A., Ballard. G, Pasquire, C. (2010) 'Lean project delivery - innovation in integrated design and delivery', Draft paper, available at: https://www.researchgate.net/publication/26482969 2_Lean_Project_Delivery_innovation_in_integrate d_design_delivery

Ndekugri, I., Daeche, H., and Zhou, D. (2013) 'The Project Insurance Option in Infrastructure Procurement', Engineering, Construction and Architectural Management, 20(3), 267-289

Nelson, R. P. and Sampat, B. N. (2001) 'Making sense of institutions as a factor shaping economic performance', Journal of Economics \& Organisation, 44, 31-54

North, D. (1994) 'Economic performance through time', The American Economic Review, 84(3), 359-368.; also published as Nobel Prize lecture, available at: http://www.nobelprize.org/nobel_prizes/economicsc iences/laureates/1993/north-lecture.html

OGC (2003) Achieving Excellence Guide 6: Procurement and Contract Strategies, H.M.S.O., London, UK.

OGC (2008), "Review of government construction procurement strategies", The Final Report of the Public Sector Construction Clients' Forum, Office of Government Commerce, Shanghai

Ohno, Taiichi (1988) Toyota Production System: Beyond large-scale production, Productivity Press, Portland, Oregon 
Oliver, C. (1991) 'Strategic responses to institutional processes' , Academy of Management Review, 16, $145-179$

Osipova, E. and Eriksson, P E. (2011) 'How Procurement Options Influence Risk management in Construction Projects' , Construction Management and Economics, 29(11), 1149-1158

Osmani, M (2012) 'Construction Waste Minimization in the UK: Current Pressures for Change and Approaches', Procedia - Social and Behavioral Sciences, 40, 37-40

Osmani, M., Glass, J., and Price, A. (2008) 'Architects' perspectives on construction waste reduction by design', Waste Management, 28, 1147-1158

Oyegoke, A., Dickinson, M., Khalfan, M., McDermott, P., and Rowlinson, S. (2009) 'Construction project procurement routes: an in depth critique', International Journal of Managing Projects in Business, 2(3), 338 - 354

Pekuri, L., Pekuri, A., and Haapasalo, H. (2014) 'Analysing the Problem of Procurement in Construction', In:, Kalsaas, B.T., Koskela, L. \& Saurin, T.A., 22nd Annual Conference of the International Group for Lean Construction, Oslo, Norway, 25-27 Jun 2014. pp 39-50

Peng, C.L., Scorpio, D.E., Kibert C.J. (1997) 'Strategies for successful construction and demolition waste recycling operations', Construction Management and Economics, 15(1), 49-58.

Peng, M. W., Sun, S. L., Pinkham, B. and Chen, H. (2009) 'The institution-based view as a third leg for a strategy tripod', Academy of Management Perspectives, 23, 63-81.

Pfeffer, J. and Salancik, G.R. (1978) The External Control of Organizations: A Resource Dependence Perspective, Harper \& Row, New York

Phua, F.T. (2006) 'When is construction partnering likely to happen? An empirical examination of the role of institutional norms', Construction Management and Economics', 24(6), 615-624

Proverbs, D.G., Holt, G.D. and Cheok, H.Y. (2000) Construction industry problems: the views of UK construction directors. In: Akintoye, A (Ed.), 16th Annual ARCOM Conference, 6-8 September 2000, Glasgow Caledonian University. Association of Researchers in Construction Management, Vol. 1, 73-81.

Rameezdeen, R and Rodrigo, A (2013) 'Textual complexity of standard conditions used in the construction industry', Australasian Journal of Construction Economics and Building, 13(1) 1-12

Rameezdeen, R. and Rajapakse, C. (2007) Contract interpretation: the impact of readability, Construction Management and Economics, 25(7), 729-737
RIBA (2013) RIBA Plan of Work 2013, Royal Institution of Building Architects

RICS (2004) Contracts in Use - A Survey of Building Contracts in Use During 2004, Royal Institution of Chartered Surveyors, Coventry.

Rindfleisch, A. and Heide, J. (1997) 'Transaction Cost Analysis: Past, Present, and Future Applications', The Journal of Marketing, 61(4), 30-54

Rooke, J., Seymour, D. and Fellows, R. (2003) 'The claims culture; A Taxonomy of attitudes in the industry', Construction Management and Economics, 21(2), 167-174

Ruan, X., Ochieng, E., Price, A., and Egbu, C. (2012) 'Knowledge Integration processes in Construction Projects: A Social Network Analysis Approach to Compare Competitive and Collaborative Working, Construction Management and Economics, 30, 5-19

Sandberg, E. and Bildsten, L. (2011) 'Coordination and waste in industrialised housing', Construction Innovation, 11(1), 77-91

Sarhan, S., and Fox, A. (2012) 'Trends and Challenges to the Development of a Lean Culture among UK Construction Organisations', Proceedings 20th Annual Conference of the IGLC, pp. 1151-1160, San Diego, USA, 18-20 July 2012; Available at: http://iglc.net/?page_id=277

Sarhan, S. and Fox, A. (2013) 'Barriers to implementing lean construction in the UK construction industry', The Built \& Human Environment Review, 6, 1-17

Sarhan, S., Pasquire, C., Manu, E., and King, A. (2016) 'Are Tier 1 Contractors Making Their Money Out of Wasteful Procurement Arrangements?' In: 24th Annual Conference of the International Group for Lean Construction, Boston, USA, 20-22, Jul 2016.

Sarhan, S., Pasquire, C., Manu, E., and King, A. (2017) 'Contractual governance as a source of institutionalised waste in construction: A review, implications, and road map for future research directions', International Journal of Managing Projects in Business, 10(3), 550-577

Pasquire, C., Sarhan, S. \& King, A. (2015). “A Critical Review of the Safeguarding Problem in Construction Procurement: Unpicking the Coherent Current Model." Proceedings of the IGLC-23, Perth, Australia, pp 309-318

Scott, W.R (2008) 'Approaching adulthood: the maturing of institutional theory', Theory and Society, 37, 427-442

Scott, W.R. (1987) 'The adolescence of institutional theory', Administrative Science Quarterly, 32, 493511

Scott, W.R. (2005). Institutional theory: contributing to a theoretical research program. In K. G. Smith, \& M. A. Hitt (Eds.), Great minds in management: the 
process of theory development. New York: Oxford University Press.

Scott, W.R. (2001) Institutions and Organizations, 2nd Ed. Foundations for Organizational Science Series, SAGE Publications, Thousand Oaks, CA

Scott, W.R. (2012) 'The institutional environment of global project organizations', Engineering Project Organization Journal, 2:1-2, 27-35,

Sha, K. (2004) 'Construction business system in China: an institutional transformation perspective', Building Research \& Information, 32(6), 529-537

Sharif, A. and Morledge, R. (1994) A functional approach to modelling procurement systems internationally and the identification of necessary support frameworks, 'Ea'st Meets West' CIB W92 Conference, Hong Kong, CIB Publication 175, pp. 295- 305.

Sherif, E and Kaka, A (2003) 'Factors influencing the selection of payment systems in construction projects', In: Greenwood, D J (Ed.), 19th Annual ARCOM Conference, 3-5 September 2003, University of Brighton, Association of Researchers in Construction Management, Vol. 1, 63-70.

Seddon, J. and Caulkin, S. (2007) 'Systems thinking, lean production and action' learning, Action Learning: Research and Practice, 4(1), 9-24

Toole, T. M. and Gambatese, J. (2008) 'The Trajectories of Construction Prevention through Design', Journal of Safety Research, 39(2), 225-230

Tookey, J., Murray, M., Hardcastle, C., and Langford, D. (2001) 'Construction procurement routes: redefining the contours of construction procurement', Engineering, Construction and Architectural Management, 8(1), 20 - 30

Viana, D., Formoso, D., and Kalsaas, B.T. (2012) ' Waste in Construction: A Systematic Literature Review on Empirical Studies', Proceedings for the IGLC-20, SanDiego, USA

Vilasini, N., Neitzert, T. and Rotimi, J. (2011) 'Correlation between Construction Procurement Methods and Lean Principles', International Journal of Construction Management, (11)4, 65-78

Walker, D., Davis, P., and Stevenson, A. (2017) 'Coping with uncertainty and ambiguity through team collaboration in infrastructure projects', International Journal of Project Management, 35 (2017), 180-190

Watermeyer, R. (2012) 'Changing the construction procurement culture to improve project outcomes', Joint CIB W070, W092 and TG72 International
Conference on Facilities Management, Procurement Systems and Public Private Partnerships, Cape Town,

Watermeyer, R. (2011) 'A framework for developing construction procurement strategy', Proceedings of the Institution of Civil Engineers - Management, procurement, and Law, 165(4), 223-237

Williamson, O.E. (1975) Markets and Hierarchies: Analysis and Antitrust Implications, New York: The Free Press

Williamson, O.E. (1985) The Economic Institutions of Capitalism: Firms, Markets, Relational Contracting, New York: The Free Press.

Williamson, O.E. (2000) The new institutional economics: Taking stock, looking ahead, Journal of Economics Literature, Vol. 38, No. 3. (Sep., 2000), pp. 595-613

Williamson, O. (1991) 'Strategizing, economizing, and economic organization', Strategic Management Journal, 12(Winter), 75-94.

Winch (2000a), 'Construction business systems in the European Union', Building Research \& Information, 28(2), 88-97

Winch, G. M. (2000b) 'Institutional reform in British construction: partnering and private finance', Building Research \& Information, 28(2), 141-155

Wordley, P. (1991) 'Protecting the building owner and occupier - latent defects insurance or collateral warranties?', Property Management, 9(3), 234 - 240

Waste and Resources Action Programme (WRAP) (2009) 'Designing out waste: a design team guide for buildings'

Xue, X., Shen, Q., and Ren, Z. (2010) 'Critical Review of Collaborative Working in Construction Projects: Business Environment and Human Behaviors', Journal of Management in Engineering, 26(4), 196208

Zaghloul, R. and Hartman, F. (2003) 'Construction contracts: the cost of mistrust', International Journal of Project Management, 21, 419-424

Zimina, D. and Pasquire, C. (2011a) 'Applying lean thinking in commercial management', Journal of Financial Management of Property and Construction, 16(1), 64-72

Zimina, D. and Pasquire, C. (2011b) 'Tracking the dependencies between companies commercial behaviour and their institutional environment', Proceedings of the IGLC-19, Peru. 
Appendix 1: A snapshot of Table of information developed for literature review purposes

\begin{tabular}{|c|c|c|c|}
\hline Study & Research Method & Main aim(s) of the study & Imperfections within the construction procurement context \\
\hline $\begin{array}{l}\text { Tookey et al. } \\
\text { (2001) }\end{array}$ & $\begin{array}{l}\text { A questionnaire based } \\
\text { on Masterman's (1994) } \\
\text { procurement } \\
\text { contentions for } \\
\text { assessment of } \\
\text { procurement choice. } \\
\text { The study targeted a } \\
\text { sample of } 12 \text { projects } \\
\text { giving permission for } \\
\text { the research team to } \\
\text { gather data. An } \\
\text { approach of elite } \\
\text { interviewing was used } \\
\text { targeting critical } \\
\text { decision makers on the } \\
\text { projects }\end{array}$ & $\begin{array}{l}\text { To identify whether clients } \\
\text { follow prescriptive } \\
\text { procurement guidelines } \\
\text { provided by academics for } \\
\text { selection of appropriate } \\
\text { procurement system }\end{array}$ & $\begin{array}{l}\text { - Clients' over-reliance on professional advice given to them } \\
\text { by consultants, which may be biased, misleading or based } \\
\text { on vested interest; } \\
\text { - The existing approach to procurement selection which is } \\
\text { based on tender cost and (imperfect) contract type dictating } \\
\text { organisational structure. For example, 'Too many clients } \\
\text { [use] Joint Contracts Tribunal (JCT) contracts even if } \\
\text { [inappropriate]' (Contracts Journal, 2000) - This selection } \\
\text { of use is often based on imitation rather than efficiency } \\
\text { reasons. As a consequence of this choice, the (imperfect) } \\
\text { contract type dictates the project-organisational structure } \\
\text { which governs the way functions interact during product } \\
\text { development. }\end{array}$ \\
\hline $\begin{array}{l}\text { Wordley } \\
\text { (1991) }\end{array}$ & $\begin{array}{l}\text { Literature review/ } \\
\text { opinion based }\end{array}$ & $\begin{array}{l}\text { To examine the respective } \\
\text { concepts of both collateral } \\
\text { warranties and Latent defects } \\
\text { insurance with a view to } \\
\text { highlighting the strengths and } \\
\text { weaknesses of each } \\
\text { arrangement. }\end{array}$ & $\begin{array}{l}\text { - Collateral warranties - vagaries of litigation together with } \\
\text { its transactional cost, delay and substantial demands on } \\
\text { management time; uncertainty about the performance of } \\
\text { the asset backing the warranty; increases the overall cost of } \\
\text { the insurance on any one project; hinders collaboration and } \\
\text { encourages disputes }\end{array}$ \\
\hline $\begin{array}{l}\text { Eriksson et } \\
\text { al. (2008) }\end{array}$ & $\begin{array}{l}\text { A survey study of } 87 \\
\text { professional } \\
\text { construction clients in } \\
\text { Sweden. }\end{array}$ & $\begin{array}{l}\text { To identify critical barriers to } \\
\text { partnering, as perceived by } \\
\text { construction clients, and the } \\
\text { specific measures that are } \\
\text { taken to overcome them } \\
\text { during implementation. }\end{array}$ & $\begin{array}{l}\text { - Cultural barriers to partnering/cooperation as identified } \\
\text { from literature: } \\
\circ \quad \begin{array}{l}\text { Short term focus - is accentuated by the clients' habit } \\
\text { of changing suppliers between projects through the } \\
\text { frequent use of open bid invitation procedures }\end{array} \\
\text { Adversarial attitudes - Win-lose situations } \\
\text { Conservative industry culture - existing values and } \\
\text { beliefs are not open for questioning } \\
\text { Lack of sub-supplier involvement in specification } \\
\text { Organisational barriers to partnering/ cooperation: } \\
\circ \quad \text { Focus on project outcomes instead of processes } \\
\text { Traditional organisation of the construction process } \\
\text { (e.g. sequential processes) } \\
\text { Traditional procurement procedures - e.g. The focus } \\
\text { on lowest price in bid evaluation } \\
\text { New competence requirements } \\
\text { Industrial barriers to partnering/cooperation: } \\
\text { Trade/Labour Unions - have a conservative and } \\
\text { defensive culture that inhibits change and encourages } \\
\text { maintenance of the status quo (Craft, 1991). An } \\
\text { example from the Swedish construction industry is } \\
\text { their requirement for piecework rates (fixed piece } \\
\text { rate for each unit produced or action performed } \\
\text { regardless of time) for blue-collar workers that do not } \\
\text { encourage collaboration between different crafts } \\
\text { Deep-rooted practice of using standard contracts } \\
\text { established by third parties - bring a formality that } \\
\text { stifles good relationships, and focus on the individual } \\
\text { parties and their responsibilities, thereby driving a } \\
\text { distance between them } \\
\text { Laws and regulations (no specific examples were } \\
\text { provided within the study) } \\
\text { Note: by using Principal component factor analysis (PCFA), } \\
\text { labour unions loaded more on the cultural barrier factor than on } \\
\text { the expected industrial barrier factor. }\end{array}$ \\
\hline
\end{tabular}

